Theories \& Applications, the International Edition

Printed Version: (ISSN 2090-5262)

Online Version: (ISSN 2090-5270)

July 2013, Volume 3, No. 2 Pages (163 - 184)

\title{
Effects of Specific Exercises on Pommel Horse "Russian" Skill Performance Level in Elite Junior Gymnasts
}

\author{
Ashraf Abdel Aal*
}

\section{Abstract \\ Introduction}

Through follow-up for Republic tournaments under 13 years researcher noticed low performance level of this skills, and Through an interview and discussion with some coaches about low performance level of this skill, their opinions were :

1. Russian skill training require great time with the importance of standardizing stages and control transition from one stage to another, which form burden on the player and requires highly experienced coaches.

2. Lack of fixed specific exercises program of this skill and this left to individual efforts of coaches, in addition to that educating this skill depends on trial and error.

So it was important to set specialist specific exercises (physical and skill) to upgrade this skill (through learning speed and arriving to mastery and fixing stages in shortest possible time), where it is basic and criteria for good performance on pommel horse, also player success in performing it is a good indicator of progress on this apparatus.

\section{Research Objectives}

- Identify the effect of the proposed specific training program on improving physical elements related to Russian skill (power, strength endurance, and flexibility) on pommel horse for gymnastics juniors

- Identify the effect of pre mentioned physical elements on improving performance level on pommel horse for gymnastics juniors.

\section{Most Important Conclusions}

- Specific exercise program lead to increase performance level for the skill under study on pommel horse for players under 13 years old.

- There are differences in players progress level which is due to individual differences represented in the following:

1. Differences in physical characteristics levels between players.

2. Differences in physical characteristics acquiring level between players

3. Differences in skill performance acquiring level between players

\section{Most Important Recommendations}

1. Using proposed training program in this research when teaching Russian skill.

2. Conducting similar studies in the skills which coaches find difficulty in teaching or developing.

* Excercises and Gymnastic Training Department, Faculty of Physical Educatoion for Men, Alexandria University, Egypt. 


\section{Introduction}

$\mathrm{G}_{\mathrm{y}}$ ymnastics developed amazingly during last years,recognized mostly in creativity and complexity of performed routines It is likely that such improvement is the result of sciencebased improvements in training methodology

The training process in gymnastics aims to enhance technical performance level with coach recognizing crucial technical elements and working on developing them simultaneously developing high level of physical fitness.

In this regard, Tudor o. Bompa (1999, p108) argue that the primary objective of specific exercises is to develop performance level of specific motor skills through developing it characteristics as it is the key factor for player excel in competition.

Watanabe (1998, p102) and Don Tonry (1997, p90) adds that skill preparation in gymnastics aims to mastery and link motor skill in routine fullil evaluation requirements as described in gymnastic rules.

By looking into ? horse technical requirements which put by the technical commeti in eygptien federationgymnastics for juniors under 13 years,for sport season2009-2010- it could be speculated that as most compulsory routine (motor sentence) end with Russian skill, mastering this skill is a good indicator of athletes progress on this apparatus.

Figure (1)

Technical performance for Russian skill (Procedural descriptions)

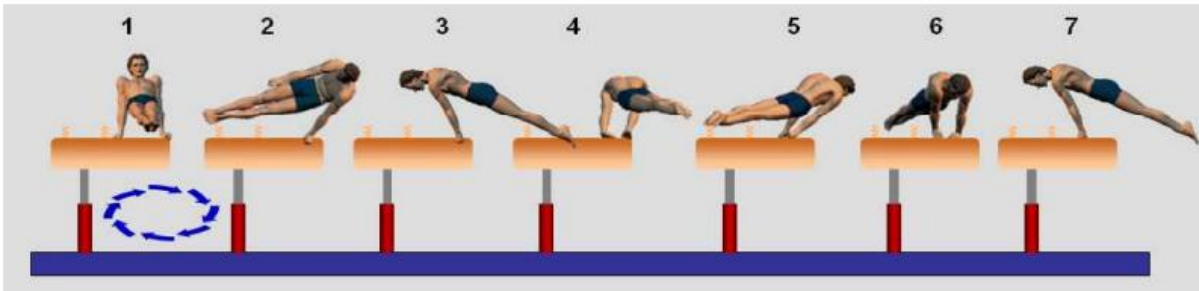

Figure (1) shows technical performance for Russian skill which can be done at the beginning in the middle or at the end and on one pommel without counting it as repetition so the value of the difficutly increases by increasing the number of rotations also it can by done on the floor exercise equipment .

Through national tournament follow-up researcher noticed low performance level of this skills,. Despite the fact that this skill set for older stages, Performing it with requirement level was in unsatisfied rate in most players routine either on pommel horse or on floor

So it was important to set specialist specific exercises (physical and skill) (through learning speed and arriving to mastery and fixing stages in shortest possible time), to upgrade this skill

Whereas specific exercises (exercises that is performed in a way identical to skill performance and at the same motor path and with the same amount of strength used) in all programs achieve marked improvement in skills performance, so they are of great importance in gymnastics. (Mohamed Alawy, Mohamed
Radwan, 1979: pp21-22), (Fawzy Yaakoub, Adel Abd ElBasir, 1982: p48), (Talha Hussain El-Din et al,1993 : p9)

El Sayed Abdel-Maksoud (1994, p18) confirmed that specific (special) exercises have dynamic matching between its path and skill motor path, with the necessity to simulate timeline in some parts of the skill, at least,

(Talha Hussain (1993, pp 57-58) indicated the importance of specific exercise and described it as exercises characterized by privacy in equicate physical skills and motor abilities in certain body parts as per requirements of gymnastics skills performance, where it works on concentrating strength amount required in muscles contraction for the proper performance and also its contraction time.

(Mohamed Ibrahim Shehata and Mohamed Mahmoud Abdel-Salam (1992, pp 394-395) and the Wesam Shawqi (1996, p5), quoting from Harra that specific exercises are used for developing correct performance of gymnastics' basic motor skills. Research objectives: 
- Identify the effect of the proposed specific training program on improving physical fitness related to Russian skill( power, strength endurance, and flexibility) on pommel horse for gymnastics juniors

- Identify the effect of specific physical elements on improving performance level on pommel horse for gymnastics juniors .

\section{Research Hypotheses}

- Specific exercises improve physical fitness related to Russian skill

- Physical fitness is related to performance level of Russian skill

\section{Research Procedures}

The researcher used the experimental approach using experimental design with two equivalence groups (experimental group, and control group) for its relevance to the study nature.
This research was conducted during the period from January to 30 March 2010 in Smouha sports club on a sample of 12 gymnastics(W,H,Years) All registered in Egyptian Federation of Gymnastics (6 from Smouha Club and 6 from Military Establishment club) sample divided into two equivalent groups in basic, skill and physical variable, sample was selected due to the following reasons:

1. Availability of appropriate number as a sample for this research.

2. Convergence of age and skill performance level for members of research sample.

3. Researcher is supervising their training and develop their training plans and programs.

4. Availability of devices and resources necessary to implement research experiment. 
Table (1)

Descriptive statistics of basic variables, physical tests and measurements, arbitrators scores for skill performance level for total sample before experiment $(n=12)$

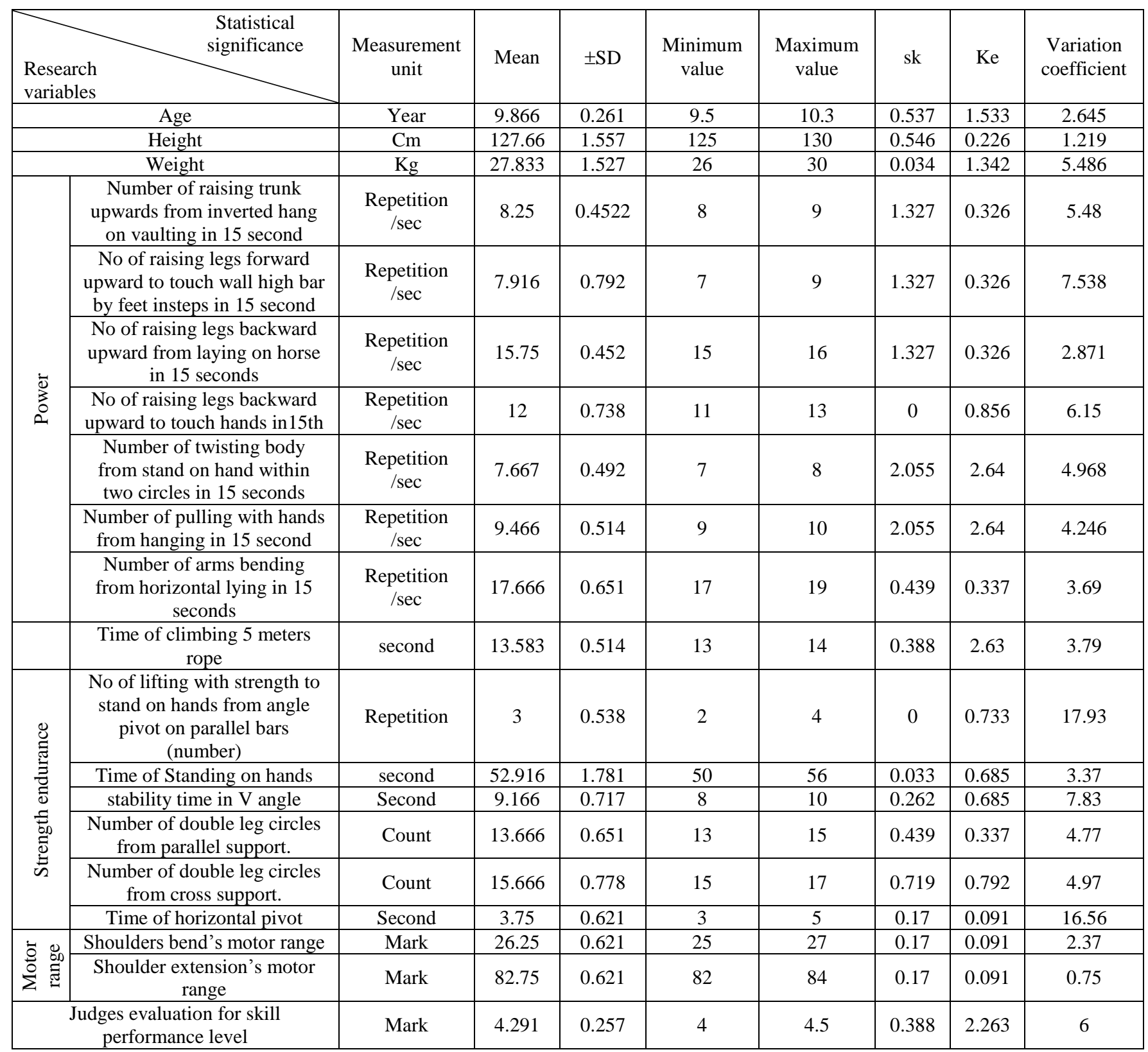

Table (1) displays statistical significance of variance coefficients are between 0.750-7.538 basic variables, physical tests and measurements, judges scores for skill performance level for total sample before evidencing sample homogeneity and all experiment and its results reveal that all skewness factors are between \pm 3 which means curve normality. 
Table (2)

Statistical significance of basic variables, physical tests and measurements, arbitrators scores for skill performance level of research groups before experiment

\begin{tabular}{|c|c|c|c|c|c|c|c|c|c|}
\hline \multirow{2}{*}{\multicolumn{3}{|c|}{$\begin{array}{l}\text { Research } \\
\text { variables }\end{array}$}} & \multirow{2}{*}{$\begin{array}{l}\text { Measuremen } \\
t \text { unit }\end{array}$} & \multicolumn{2}{|c|}{$\begin{array}{l}\text { Experimental group } \\
n=6\end{array}$} & \multicolumn{2}{|c|}{$\begin{array}{l}\text { Control group } \\
n=6\end{array}$} & \multirow{2}{*}{$\begin{array}{l}\text { Difference } \\
\text { Between } \\
\text { means }\end{array}$} & \multirow{2}{*}{$\mathrm{T}$ value } \\
\hline & & & & Mean & $\pm \mathrm{SD}$ & Mean & $\pm \mathrm{SD}$ & & \\
\hline & Age & & Year & 9.866 & 0.294 & 9.866 & 0.294 & 0 & 0 \\
\hline & Height & & $\mathrm{Cm}$ & 127.833 & 1.722 & 127.5 & 1.516 & 0.333 & 0.356 \\
\hline & Weight & & $\mathrm{Kg}$ & 27.833 & 1.602 & 27.833 & 1.602 & 0 & 0 \\
\hline \multirow{8}{*}{$\begin{array}{l}\overline{0} \\
\vdots \\
0 \\
0\end{array}$} & \multicolumn{2}{|c|}{$\begin{array}{l}\text { Number of raising trunk } \\
\text { upwards from inverted hang } \\
\text { on vaulting in } 15 \text { second }\end{array}$} & $\begin{array}{l}\text { Repetition } \\
\quad / \mathrm{sec}\end{array}$ & 8.333 & 0.516 & 8.166 & 0.408 & 1.666 & 0.62 \\
\hline & \multicolumn{2}{|c|}{$\begin{array}{l}\text { No of raising legs forward } \\
\text { upward to touch wall high } \\
\text { bar by feet insteps in } 15 \\
\text { second }\end{array}$} & $\begin{array}{l}\text { Repetition } \\
\quad / \mathrm{sec}\end{array}$ & 8 & 0.894 & 7.833 & 0.752 & 0.167 & 0.349 \\
\hline & \multicolumn{2}{|c|}{$\begin{array}{l}\text { No of raising legs backward } \\
\text { upward from laying on } \\
\text { horse in } 15 \text { seconds }\end{array}$} & $\begin{array}{l}\text { Repetition } \\
\quad / \mathrm{sec}\end{array}$ & 15.833 & 0.408 & 15.666 & 0.516 & 0.166 & 0.62 \\
\hline & \multicolumn{2}{|c|}{$\begin{array}{l}\text { No of raising legs backward } \\
\text { upward to touch hands } \\
\text { in15th }\end{array}$} & $\begin{array}{l}\text { Repetition } \\
\quad / \mathrm{sec}\end{array}$ & 12.166 & 0.752 & 11.833 & 0.752 & 0.333 & 0.767 \\
\hline & \multicolumn{2}{|c|}{$\begin{array}{l}\text { Number of twisting body } \\
\text { from stand on hand within } \\
\text { two circles in } 15 \text { seconds }\end{array}$} & $\begin{array}{l}\text { Repetition } \\
\text { /sec }\end{array}$ & 7.677 & 0.516 & 7.667 & 0.516 & 0 & 0 \\
\hline & \multicolumn{2}{|c|}{$\begin{array}{l}\text { Number of pulling with } \\
\text { hands from hanging in } 15 \\
\text { second }\end{array}$} & $\begin{array}{l}\text { Repetition } \\
\quad / \mathrm{sec}\end{array}$ & 9.5 & 0.547 & 9.333 & 0.516 & 0.167 & 0.542 \\
\hline & \multicolumn{2}{|c|}{$\begin{array}{l}\text { Number of arms bending } \\
\text { from horizontal lying in } 15 \\
\text { seconds }\end{array}$} & $\begin{array}{l}\text { Repetition } \\
\text { /sec }\end{array}$ & 17.833 & 0.852 & 17.5 & 0.547 & 0.333 & 0.877 \\
\hline & \multicolumn{2}{|c|}{$\begin{array}{l}\text { Time of climbing } 5 \text { meters } \\
\text { rope }\end{array}$} & second & 13.5 & 0.547 & 13.666 & 0.516 & 0.166 & 0.542 \\
\hline \multirow{6}{*}{ 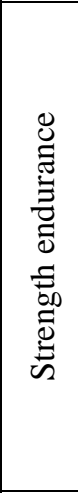 } & \multicolumn{2}{|c|}{$\begin{array}{l}\text { No of lifting with strength } \\
\text { to stand on hands from } \\
\text { angle pivot on parallel bars } \\
\text { (number) }\end{array}$} & Repetition & 3 & 0.894 & 3 & 0.632 & 0 & 0 \\
\hline & \multicolumn{2}{|c|}{ Time of Standing on hands } & second & 52.5 & 1.87 & 53.333 & 1.751 & 0.833 & 0.797 \\
\hline & \multicolumn{2}{|c|}{ stability time in $V$ angle } & Second & 9 & 0.894 & 9.333 & 0.516 & 0.333 & 0.791 \\
\hline & \multicolumn{2}{|c|}{$\begin{array}{c}\text { Number of double leg } \\
\text { circles from parallel } \\
\text { support. }\end{array}$} & Count & 13.333 & 0.516 & 14 & 0.632 & 0.666 & 3 \\
\hline & \multicolumn{2}{|c|}{$\begin{array}{l}\text { Number of double leg } \\
\text { circles from cross support. }\end{array}$} & Count & 15.333 & 0.516 & 16 & 0.894 & 0.666 & 0.1851 \\
\hline & \multicolumn{2}{|c|}{ Time of horizontal pivot } & Second & 3.833 & 0.753 & 3.667 & 0.516 & 0.166 & 2.447 \\
\hline \multirow{2}{*}{ 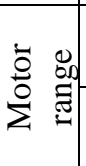 } & \multicolumn{2}{|c|}{$\begin{array}{c}\text { Shoulders bend's motor } \\
\text { range }\end{array}$} & Mark & 26.5 & 0.547 & 26 & 0.632 & 0.5 & 1.464 \\
\hline & \multicolumn{2}{|c|}{$\begin{array}{c}\text { Shoulder extension's motor } \\
\text { range }\end{array}$} & Mark & 82.666 & 0.516 & 82.833 & 0.752 & 0.166 & 0.447 \\
\hline \multicolumn{3}{|c|}{$\begin{array}{l}\text { Judges evaluation for skill } \\
\text { performance level }\end{array}$} & Mark & 4.333 & 0.258 & 4.25 & 0.273 & 0.083 & 0.542 \\
\hline
\end{tabular}

\section{T significant (at 0.05 level $)=2.45$}

Table No. (2) displays basic variables, physical tests and measurements, judges scores for skill performance level for research groups before experiment and its results reveal that there is no statistically significant differences at 0.05 confidence level between the two groups before experience. Therefore, we can return this to several factors can be summarized as follows:

Sample subjects are the same (climatic, education, training) conditions as they are living in the same residential area and playing in clubs in same area, and sample subjects are 
characterized by average or below average performance level of this skill, sample equivalence in age stage (see sample selection terms), and random distribution of research sample to research groups.

\section{Research Procedural Steps}

I Determining muscle work for Russian skill, then classifying at as per muscle work type

II Setting specific exercises:

Specific exercises for Russian skill have been developed ( appendix 3) with reference to:

- Skill motor structure (introductory phase main phase - final phase)

- Previous analysis for muscle work related to skill performance.

- Seeking experts opinions.

- Analysing some educational films produced by International Gymnastics Federation.

While selecting and setting specific exercises the following have been considered

\section{Dividing the skill technically:}

- Dividing skill performance on low mushrooms apparatus (without rings) into four equal parts

- Moving to difficult level in skill performance only after mastering the less difficult level.

- Working and correspondence muscles during the skill performance (1997: p87)

- Difficulty progression.

- Contains the main part of the skill.

- Be easier than skill performance.

- Identify type of muscle contraction used .

- Determine training ways and methods for each strength form (periodic training with low and high intensity related to strength).

- Identify physical level research sample players.

\section{III physical and skill tests:}

Researcher identified most important tests that measure physical and skill fitness elements which related to Russian skill on pommel horse (appendix 2) and by analyzing scientific references and research and previous studies (Ahmed ELhady,1997) (Fawzy Yakob, Adel Abd El basir, 1982) (Atiat Khatab, 1987) (Mohamed ALawy, M. Nasr El-Din Radwan, 1979) (Mohamed ALawy, M. Nasr El-Din Radwan, 1982) (Mohamed Sobhy Hassanin, 1995) (Mohab Abd ELRazek et al, 2004) (Wessam Zaki, 1996) (Gensen,C.R and Hirst, C.C. 1980 )

The following have been considered in these tests:

1. fulfilling scientific Conditions (validity, stability and objective) for selected tests.

2. Already implemented on samples similar to research sample.

3. Can be applied smoothly and easily with the availability of tools

These tests are:

\section{Physical tests:}

\section{Power:}

1. Number of raising trunk upwards from inverted hang on vaulting in 15 second

2. No of raising legs forward upward to touch wall high bar by feet insteps in 15 second

3. No of raising legs backward upward from laying on horse in 15 seconds

4. No of raising legs backward upward to touch tester hands in 15 th

5. Number of twisting body from stand on hand within two circles in 15 seconds

6. Number of pulling with hands from hanging in 15 second

7. Number of arms bending from horizontal lying in 15 seconds

8. Time of climbing 5 meters rope

9. Horizontal pivot open

\section{Skill endurance tests}

1. No of lifting with strength to stand on hands from angle pivot on parallel bars (number)

2. Time of Standing on hands (seconds)

3. stability time in V angle (seconds) 
4. Number of side waving from parallel pivot (number)

5. Number of side waving from crossed pivot (number)

\section{Flexibility:}

1. Shoulders bend's motor range

2. Shoulder extension's motor range

\section{Pilot studies:}

1. Identifying how physical characteristics correlate with the skill under study.
This study was conducted in during the period from $1 / 12$ to $5 / 12 / 2010$ and was aimed to identify:

- Measurements and tests appropriateness for the motor skill.

- The best order of performing these measurements and tests to get best result.

- Measurements and tests appropriateness for the age stage.

- Equipments efficiency.

- Determine the difficulties that face the researcher during measurement.

Table (3)

Correlation coefficients between arbitrators scores for skill under study's performance level and physical measurements for experimental group, control group and both groups

\begin{tabular}{|c|c|c|c|c|}
\hline \multicolumn{2}{|r|}{ Research variables } & $\begin{array}{l}\text { Experimental } \\
\text { group }\end{array}$ & $\begin{array}{l}\text { Control } \\
\text { group }\end{array}$ & $\begin{array}{l}\text { Both } \\
\text { groups }\end{array}$ \\
\hline \multirow{8}{*}{$\begin{array}{l}\overline{0} \\
\vdots \\
0 \\
0\end{array}$} & Number of raising trunk upwards from inverted hang on vaulting in 15 second & 0.938 & 0.874 & 0.906 \\
\hline & $\begin{array}{l}\text { No of raising legs forward upward to touch wall high bar by feet insteps in } 15 \\
\text { second }\end{array}$ & 0.896 & 0.617 & 0.805 \\
\hline & No of raising legs backward upward from laying on horse in 15 seconds & 0.9 & 0.605 & 0.848 \\
\hline & No of raising legs backward upward to touch hands in 15 th & 0.846 & 0.596 & 0.792 \\
\hline & Number of twisting body from stand on hand within two circles in 15 seconds & 0.963 & 0.801 & 0.862 \\
\hline & Number of pulling with hands from hanging in 15 second & 0.901 & 0.656 & 0.84 \\
\hline & Number of arms bending from horizontal lying in 15 seconds & 0.857 & 0.756 & 0.895 \\
\hline & Time of climbing 5 meters rope & 0.868 & 0.176 & 0.534 \\
\hline \multirow{6}{*}{ 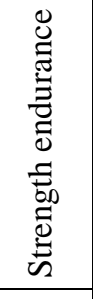 } & $\begin{array}{l}\text { No of lifting with strength to stand on hands from angle pivot on parallel bars } \\
\text { (number) }\end{array}$ & 0.917 & 0.782 & 0.9 \\
\hline & Time of Standing on hands & 0.936 & 0.658 & 0.886 \\
\hline & stability time in $\mathrm{V}$ angle & 0.935 & 0.772 & 0.895 \\
\hline & Number of double leg circles from parallel support. & 0.985 & 0.814 & 0.928 \\
\hline & Number of double leg circles from cross support. & 0.971 & 0.814 & 0.934 \\
\hline & Time of horizontal pivot & 0.945 & 0.588 & 0.851 \\
\hline \multirow{2}{*}{ 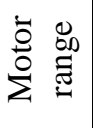 } & Shoulders bend's motor range & 0.948 & 0.521 & 0.848 \\
\hline & Shoulder extension's motor range & 0.898 & 0.376 & 0.841 \\
\hline
\end{tabular}

Table (3) reveals presence high correlation between arbitrators scores for skill under study's performance level and physical measurements for experimental group, control group and both groups, and so these measurements are appropriate to selected age stage

2. This study was conducted in the period from 12 to $15 / 12 / 2010$, The aim was to identify:

- Exercises appropriateness or players age stage.

- Arranging exercises according to its difficulty degree.
- Identify players maximum performance in each exercise, to make formation of training load possible.

- Determine physical and skill tests appropriateness for the age stage and identify the difficulties that may face performing it, with classifying it as per muscles work groups.

Through pilot studies it was possible to:

- Identify appropriate specific exercises.

- Arranging exercises in sequence according to its difficulty degree. 
- Maximum players' performance for each exercise have been identified and through which formation of training was possible with consideration of individual differences during training sessions of proposed program

\section{$\mathrm{V}$ assess the skill level of performance:}

Researcher has identified skill level study sample through arbitrators, whether before, during or after experiment and got the players score for performing Russian skill as it is performed with compulsory routine for age stage under (13) years.

\section{VI proposed training program:}

Proposed specific exercise was set in form of proposed program, time allocated for this skill has been deducted from the traditional program and was forms in proposed program cope with the set program.

\section{Program Objectives}

1. Development physical fitness elements related to skill under study.

2. Educating and training of skill under study to improve its skill performance level.

\section{Program timetable}

Total program time has been determined as follows:

- Number of weeks of proposed exercises program is: (12) weeks in three months.

- Number of training sessions per week (6) sessions.

- Number of apparatuses used in training in one session $=$ three apparatuses

- Time module $=240$ minutes and is divided as follows:

Session unit time is 240 minutes devided as follows:

warm up

1st apparatus

2nd apparatus

3rd apparatus

Special physical preparation 60 minutes.

Time training on the pommel horse during the program period is calculated as follows:
- Skill training time on the apparatus (45 minutes) $\mathrm{x}$ apparatus training days (3 days weekly) $\mathrm{x}$ number of weeks (12 weeks) $=45$ x $3 \times 12=1620$ minutes

- Physical training time on the apparatus $=60$ minutes divided by number of apparatuses (6) - 10 minutes for each apparatus at each training session.

\section{Pre- measurements:}

- Pre-measurements from conducted durimg the period from 21/12/2009 to 28/12/2009 for all variables under consideration.

- Research experiment application:

- Research experiment has been applied in the period from 1/1/2010- 28/3/2010 and for a period of three consecutive months at Military Establishment and Smouha Clubs

- In-between measurements:

- In-between were conducted in the period from $21 / 2 / 2010-14 / 2 / 2010$ in all variables under consideration.

- Post- measurements:

- Post measurements were carried out in the period from 29/3/2010 to 30/3/2010 for all variables under consideration.

\section{Statistical work:}

Statistical work were carried out on row data using SPSS program to obtain for:

Mean.

Standard deviation.

Skewness Coefficient.

$\mathrm{T}$ Test.

F test.

LSD test

Improvement ratios.

\section{Results and discussion}

I. Results and discussion for research groups in the middle of the experiment

Results and discussion for research groups in the middle of the experiment

II. Results and discussion for research groups in the during the experiment 
Results and discussion for experimental group in the during the experiment
Results and discussion for control groups in the during the experiment

\section{Results and discussion for research groups in the middle of the experiment}

Table (4)

Statistical significance of basic variables, physical tests and measurements, judges scores for skill performance level of research groups at middle of experiment

\begin{tabular}{|c|c|c|c|c|c|c|c|c|}
\hline \multirow{2}{*}{\multicolumn{2}{|c|}{$\begin{array}{l}\text { Research } \\
\text { variables }\end{array}$}} & \multirow{3}{*}{$\begin{array}{c}\text { Measurement } \\
\text { unit } \\
\begin{array}{c}\text { Repetition } \\
/ \mathrm{sec}\end{array} \\
\end{array}$} & \multicolumn{2}{|c|}{$\begin{array}{l}\text { Experimental } \\
\text { group } \\
\mathrm{n}=6\end{array}$} & \multicolumn{2}{|c|}{$\begin{array}{l}\text { Control group } \\
\qquad \mathrm{n}=6\end{array}$} & \multirow{3}{*}{ 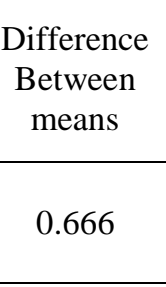 } & \multirow{3}{*}{$\begin{array}{c}\mathrm{T} \\
\text { value } \\
2.828\end{array}$} \\
\hline & & & \multirow{2}{*}{$\begin{array}{l}\text { Mean } \\
9.8333\end{array}$} & \multirow{2}{*}{$\begin{array}{c} \pm \text { SD } \\
0.40825\end{array}$} & \multirow{2}{*}{$\begin{array}{l}\text { Mean } \\
9.166\end{array}$} & \multirow{2}{*}{$\begin{array}{l} \pm \mathrm{SD} \\
0.408\end{array}$} & & \\
\hline \multirow{8}{*}{ 离 } & $\begin{array}{l}\text { Number of raising trunk upwards } \\
\text { from inverted hang on vaulting in } \\
15 \text { second }\end{array}$ & & & & & & & \\
\hline & $\begin{array}{c}\text { No of raising legs forward upward } \\
\text { to touch wall high bar by feet } \\
\text { insteps in } 15 \text { second }\end{array}$ & $\begin{array}{l}\text { Repetition } \\
\quad / \mathrm{sec}\end{array}$ & 9.8333 & 0.405 & 9 & 0.894 & 0.833 & 2.076 \\
\hline & $\begin{array}{l}\text { No of raising legs backward } \\
\text { upward from laying on horse in } 15 \\
\text { seconds }\end{array}$ & $\begin{array}{l}\text { Repetition } \\
\quad / \mathrm{sec}\end{array}$ & 17.166 & 0.405 & 16 & 0.632 & 1.166 & 3.796 \\
\hline & $\begin{array}{l}\text { No of raising legs backward } \\
\text { upward to touch hands in } 15 \text { th }\end{array}$ & $\begin{array}{l}\text { Repetition } \\
\text { /sec }\end{array}$ & 14 & 0.894 & 12.833 & 0.752 & 1.166 & 2.445 \\
\hline & $\begin{array}{l}\text { Number of twisting body from } \\
\text { stand on hand within two circles in } \\
15 \text { seconds }\end{array}$ & $\begin{array}{l}\text { Repetition } \\
\quad / \mathrm{sec}\end{array}$ & 11.666 & 0.516 & 11 & 0.632 & 0.666 & 3 \\
\hline & $\begin{array}{l}\text { Number of pulling with hands from } \\
\text { hanging in } 15 \text { second }\end{array}$ & $\begin{array}{l}\text { Repetition } \\
\text { /sec }\end{array}$ & 11.1666 & 0.408 & 9.833 & 0.762 & 1.333 & 3.814 \\
\hline & $\begin{array}{l}\text { Number of arms bending from } \\
\text { horizontal lying in } 15 \text { seconds }\end{array}$ & $\begin{array}{l}\text { Repetition } \\
/ \mathrm{sec}\end{array}$ & 20.35 & 0.408 & 18.5 & 0.547 & 2 & 4.899 \\
\hline & Time of climbing 5 meters rope & second & 12.966 & 0.516 & 12.5 & 2.345 & 0.166 & 0.17 \\
\hline \multirow{6}{*}{ 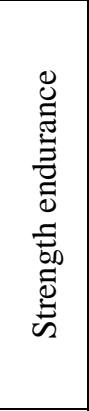 } & $\begin{array}{c}\text { No of lifting with strength to stand } \\
\text { on hands from angle pivot on } \\
\text { parallel bars (number) }\end{array}$ & Repetition & 7.666 & 0.816 & 4.667 & 0.516 & 3 & 7.606 \\
\hline & Time of Standing on hands & second & 62.166 & 1.416 & 55.833 & 0.752 & 3 & 7.606 \\
\hline & stability time in $\mathrm{V}$ angle & Second & 17.5 & 2.949 & 12.666 & 0.516 & 6.333 & 9.383 \\
\hline & $\begin{array}{l}\text { Number of double leg circles from } \\
\text { parallel support. }\end{array}$ & Count & 25.833 & 1.471 & 22.333 & 1.632 & 4.833 & 3.954 \\
\hline & $\begin{array}{l}\text { Number of double leg circles from } \\
\text { cross support. }\end{array}$ & Count & 28.166 & 2.169 & 22.833 & 1.722 & 3.5 & 3.9 \\
\hline & Time of horizontal pivot & Second & 5.5 & 0.547 & 4.333 & 0.211 & 1.167 & 3.769 \\
\hline \multirow{2}{*}{ 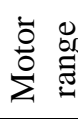 } & Shoulders bend's motor range & Mark & 32.166 & 0.752 & 26.666 & 0.516 & 5.333 & 6.276 \\
\hline & Shoulder extension's motor range & Mark & 87.166 & 1.69 & 83.5 & 0.547 & 5.5 & 14.758 \\
\hline \multicolumn{2}{|c|}{$\begin{array}{c}\text { Judges evaluation for skill performance } \\
\text { level }\end{array}$} & Mark & 6.5833 & 0.37639 & 4.8333 & 0.7527 & 1.75 & 6.957 \\
\hline
\end{tabular}

\section{T significant (at 0.05 level) $=2.45$}

From Table (4) which displays Statistical significance of basic variables, physical tests and measurements, judges scores for skill performance level of research groups at middle of experiment, superiority of experimental group over control group in this stage (i.e. after six weeks) is clear with statistically significant differences at 0.05 significance level, in most of physical measurements which form $76.461 \%$ from total measurements. As well as in judges scores for performance level of skill under study. For example number of bend arms from horizontal lying was 20.50 times for experimental group which is larger (better) than the control group 18.500 times with difference of 2.000 times and this difference significant at level $0.05, T=4.8999$ Table (4)

From the above mentioned, we can say that experimental group which followed the propose specific program using special exercises for developing power, strength endurance, flexibility and motor range, in addition to the 
unified skill program has made remarkable progress in the middle of the experiment more than the control group that followed traditional training program for developing pre-mentioned physical abilities, in addition to unified training program

\section{Results and discussion for research groups after the experiment}

Table (5)

Statistical significance of basic variables, physical tests and measurements, judges scores for skill performance level of research groups after experiment

\begin{tabular}{|c|c|c|c|c|c|c|c|c|}
\hline \multirow{2}{*}{\multicolumn{2}{|c|}{$\begin{array}{l}\text { Research } \\
\text { variables }\end{array}$}} & \multirow{3}{*}{$\begin{array}{c}\begin{array}{c}\text { Measurement } \\
\text { unit }\end{array} \\
\begin{array}{c}\text { Repetition } \\
\text { /sec }\end{array} \\
\end{array}$} & \multicolumn{2}{|c|}{$\begin{array}{l}\text { Experimental } \\
\text { group } \\
n=6\end{array}$} & \multicolumn{2}{|c|}{$\begin{array}{l}\text { Control group } \\
\qquad \mathrm{n}=6\end{array}$} & \multirow{3}{*}{$\begin{array}{c}\begin{array}{c}\text { Difference } \\
\text { Between } \\
\text { means }\end{array} \\
0.666\end{array}$} & \multirow{3}{*}{$\begin{array}{c}\mathrm{T} \\
\text { value }\end{array}$} \\
\hline & & & \multirow{2}{*}{$\begin{array}{l}\text { Mean } \\
10.833\end{array}$} & \multirow{2}{*}{$\begin{array}{l} \pm \mathrm{SD} \\
0.408\end{array}$} & \multirow{2}{*}{$\begin{array}{l}\text { Mean } \\
10.166\end{array}$} & \multirow{2}{*}{\begin{tabular}{|l|}
$\mathrm{SD}$ \\
0.408
\end{tabular}} & & \\
\hline \multirow{8}{*}{$\begin{array}{l}\dot{0} \\
\grave{0} \\
0\end{array}$} & $\begin{array}{l}\text { Number of raising trunk upwards } \\
\text { from inverted hang on vaulting in } \\
15 \text { second }\end{array}$ & & & & & & & \\
\hline & $\begin{array}{l}\text { No of raising legs forward upward } \\
\text { to touch wall high bar by feet } \\
\text { insteps in } 15 \text { second }\end{array}$ & $\begin{array}{l}\text { Repetition } \\
\quad / \mathrm{sec}\end{array}$ & 10.833 & 0.408 & 9.833 & 0.752 & 1 & 3.873 \\
\hline & $\begin{array}{l}\text { No of raising legs backward } \\
\text { upward from laying on horse in } 15 \\
\text { seconds }\end{array}$ & $\begin{array}{l}\text { Repetition } \\
\quad / \mathrm{sec}\end{array}$ & 18.166 & 0.408 & 16.666 & 0.516 & 1.5 & 5.582 \\
\hline & $\begin{array}{l}\text { No of raising legs backward } \\
\text { upward to touch hands in } 15 \text { th }\end{array}$ & $\begin{array}{l}\text { Repetition } \\
\text { /sec }\end{array}$ & 15 & 0.894 & 13.833 & 0.752 & 1.167 & 2.15 \\
\hline & $\begin{array}{c}\text { Number of twisting body from } \\
\text { stand on hand within two circles in } \\
15 \text { seconds }\end{array}$ & $\begin{array}{l}\text { Repetition } \\
\quad / \mathrm{sec}\end{array}$ & 13.833 & 0.408 & 12.833 & 0.408 & 1 & 2.729 \\
\hline & $\begin{array}{l}\text { Number of pulling with hands from } \\
\text { hanging in } 15 \text { second }\end{array}$ & $\begin{array}{l}\text { Repetition } \\
\text { /sec }\end{array}$ & 11.833 & 0.408 & 10.833 & 0.752 & 1 & 2.739 \\
\hline & $\begin{array}{l}\text { Number of arms bending from } \\
\text { horizontal lying in } 15 \text { seconds }\end{array}$ & $\begin{array}{l}\text { Repetition } \\
\text { /sec }\end{array}$ & 21.5 & 0.836 & 19.5 & 0.536 & 2 & 7.746 \\
\hline & Time of climbing 5 meters rope & second & 10.5 & 0.547 & 12.8333 & 2.639 & 2.333 & 2.214 \\
\hline \multirow{6}{*}{ 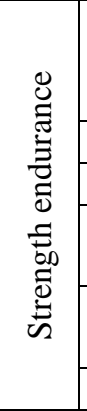 } & $\begin{array}{c}\text { No of lifting with strength to stand } \\
\text { on hands from angle pivot on } \\
\text { parallel bars (number) }\end{array}$ & Repetition & 0.9333 & 1.032 & 6 & 0.894 & 3.333 & 5.976 \\
\hline & Time of Standing on hands & second & 64.5 & 1.87 & 57 & 0.894 & 7.5 & 8.859 \\
\hline & stability time in $\mathrm{V}$ angle & Second & 22.5 & 1.048 & 14 & 0.532 & 8.5 & 17 \\
\hline & $\begin{array}{l}\text { Number of double leg circles from } \\
\text { parallel support. }\end{array}$ & Count & 32.333 & 0.816 & 25.5 & 1.048 & 6.833 & 12.593 \\
\hline & $\begin{array}{l}\text { Number of double leg circles from } \\
\text { cross support. }\end{array}$ & Count & 33.333 & 0.816 & 25.666 & 1.032 & 7.666 & 14.264 \\
\hline & Time of horizontal pivot & Second & 7.166 & 0.753 & 4.666 & 0.516 & 2.5 & 26.708 \\
\hline \multirow{2}{*}{ 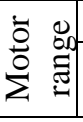 } & Shoulders bend's motor range & Mark & 34.333 & 1.211 & 27.5 & 0.547 & 6.833 & 12.593 \\
\hline & Shoulder extension's motor range & Mark & 89 & 0.894 & 83.666 & 0.816 & 5.333 & 10.787 \\
\hline \multicolumn{2}{|c|}{$\begin{array}{c}\text { Judges evaluation for skill performance } \\
\text { level }\end{array}$} & Mark & 8.333 & 0.258 & 6.5 & 0.316 & 1.833 & 11 \\
\hline
\end{tabular}

\section{T significant $($ at 0.05 level $)=2.45$}

From Table (5) which displays Statistical significance of basic variables, physical tests and measurements, judges scores for skill performance level of research groups after experiment, superiority of experimental group over control group in this stage is also clear with statistically significant differences at 0.05 level, in most of physical measurements which form $88.235 \%$ from total measurements. As well as in judges scores for performance level of skill under study. For example time of angular stability was 22.5 second for experimental group which is larger (better) than control group 14.000 seconds with difference of 0.5000 second and this difference significant at level $0.05, \mathrm{~T}=17.000$ Table (5)

From the above mentioned, we can say that experimental group which followed the proposed specific program using special exercises for developing power, strength endurance, and motor range, in addition to the 
unified skill program has made remarkable progress after the experiment more than the control group that followed traditional training program for same pre-mentioned physical abilities, in addition to unified training program.

So, it can be concluded that experimental group made significant progress over control group, this can be attributed to great similarity between time path for power, strength endurance, motor range, and judges scores for skill performance level during specific developed exercises in proposed training program which followed by the experimental group during the two stages (Support on hands - transition with hands in a 360 degree circle while keeping rest of the body extended in horizontal level in space). Accordingly, we can recommend that development of power and other elements should not be intended for itself without relating it to skill performance nature.

\section{Results and discussion for research groups during the experiment}

A. Results and discussion for experimental group during the experiment

Table (6)

Statistical significance of basic variables, physical tests and measurements, judges scores for skill performance level of experimental group during experiment

\begin{tabular}{|c|c|c|c|c|c|c|c|c|c|}
\hline \multirow{2}{*}{\multicolumn{2}{|c|}{ Research $\quad \begin{array}{c}\text { Statistical } \\
\text { significance }\end{array}$}} & \multirow{2}{*}{$\begin{array}{l}\text { Measurement } \\
\text { unit }\end{array}$} & \multicolumn{2}{|c|}{ Pre- measurement } & \multicolumn{2}{|c|}{$\begin{array}{c}\text { In-between } \\
\text { measurement }\end{array}$} & \multicolumn{2}{|c|}{ Post- measurement } & \multirow{2}{*}{ F value } \\
\hline & & & Mean & $\pm \mathrm{SD}$ & Mean & $\pm \mathrm{SD}$ & Mean & $\pm \mathrm{SD}$ & \\
\hline \multirow{8}{*}{$\sum_{0}^{10}$} & $\begin{array}{l}\text { Number of raising trunk } \\
\text { upwards from inverted hang on } \\
\text { vaulting in } 15 \text { second }\end{array}$ & $\begin{array}{l}\text { Repetition } \\
\text { /sec }\end{array}$ & 8.333 & 0.516 & 9.832 & 0.408 & 10.833 & 0.408 & 47.500 \\
\hline & $\begin{array}{l}\text { No of raising legs forward } \\
\text { upward to touch wall high bar } \\
\text { by feet insteps in } 15 \text { second }\end{array}$ & $\begin{array}{l}\text { Repetition } \\
\text { /sec }\end{array}$ & 8.000 & 0.894 & 9.833 & 0.408 & 10.833 & 0.408 & 32.798 \\
\hline & $\begin{array}{l}\text { No of raising legs backward } \\
\text { upward from laying on horse in } \\
15 \text { seconds }\end{array}$ & $\begin{array}{l}\text { Repetition } \\
\text { /sec }\end{array}$ & 15.833 & 0.408 & 17.166 & 0.408 & 18.166 & 0.408 & 49.333 \\
\hline & $\begin{array}{l}\text { No of raising legs backward } \\
\text { upward to touch hands in } 15 \text { th }\end{array}$ & $\begin{array}{l}\text { Repetition } \\
\text { /sec }\end{array}$ & 12.166 & 0.752 & 14.000 & 0.894 & 15.000 & 0.894 & 17.154 \\
\hline & $\begin{array}{l}\text { Number of twisting body from } \\
\text { stand on hand within two circles } \\
\text { in } 15 \text { seconds }\end{array}$ & $\begin{array}{l}\text { Repetition } \\
\text { /sec }\end{array}$ & 7.666 & 0.516 & 11.666 & 0.516 & 13.833 & 0.408 & 251.667 \\
\hline & $\begin{array}{l}\text { Number of pulling with hands } \\
\text { from hanging in } 15 \text { second }\end{array}$ & $\begin{array}{l}\text { Repetition } \\
\text { /sec }\end{array}$ & 9.500 & 0.547 & 11.166 & 0.408 & 11.833 & 0.408 & 41.035 \\
\hline & $\begin{array}{l}\text { Number of arms bending from } \\
\text { horizontal lying in } 15 \text { seconds }\end{array}$ & $\begin{array}{l}\text { Repetition } \\
\text { /sec }\end{array}$ & 17.833 & 0.752 & 20.500 & 0.836 & 21.500 & 0.836 & 32.881 \\
\hline & Time of climbing 5 meters rope & second & 13.500 & 0.547 & 12.666 & 0.516 & 10.500 & 0.547 & 49.808 \\
\hline \multirow{5}{*}{ 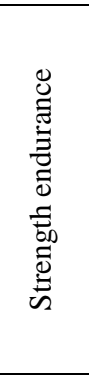 } & $\begin{array}{l}\text { No of lifting with strength to } \\
\text { stand on hands from angle pivot } \\
\text { on parallel bars (number) }\end{array}$ & Repetition & 3.000 & 0.894 & 7.666 & 0.816 & 9.333 & 1.032 & 76.579 \\
\hline & Time of Standing on hands & second & 52.500 & 1.870 & 62.166 & 1.416 & 64.500 & 1.870 & 79.491 \\
\hline & stability time in $\mathrm{V}$ angle & Second & 9.000 & 0.894 & 17.500 & 2.949 & 22.500 & 1.048 & 79.104 \\
\hline & $\begin{array}{l}\text { Number of double leg circles } \\
\text { from parallel support. }\end{array}$ & Count & 13.333 & 0.516 & 25.832 & 0.471 & 32.333 & 0.816 & 541.450 \\
\hline & $\begin{array}{l}\text { Number of double leg circles } \\
\text { from cross support. }\end{array}$ & Count & 15.333 & 0.516 & 28.166 & 1.169 & 33.333 & 0.816 & 672.240 \\
\hline \multirow{2}{*}{$\begin{array}{l}\dot{0} 0 \\
\stackrel{0}{0} \\
\dot{0}\end{array}$} & Shoulders bend's motor range & Mark & 26.000 & 0.547 & 32.116 & 0.752 & 34.333 & 1.211 & 126.214 \\
\hline & $\begin{array}{l}\text { Shoulder extension's motor } \\
\text { range }\end{array}$ & Mark & 82.666 & 0.516 & 87.166 & 1.169 & 89.000 & 0.894 & 78.562 \\
\hline \multicolumn{2}{|c|}{$\begin{array}{l}\text { Judges evaluation for skill performance } \\
\text { level }\end{array}$} & Mark & 4.333 & 0.258 & 6.583 & 0.376 & 8.333 & 0.258 & 263.182 \\
\hline
\end{tabular}

F significant $\quad($ at 0.01 level $)=3.68$

$($ at 0.01 level $)=6.26$ 
Table (7)

Significance of difference between the three measurements (pre, in-between and post) for basic variables, physical tests and measurements, judges scores for skill performance level of experimental group using LSD test

\begin{tabular}{|c|c|c|c|c|c|c|c|c|c|}
\hline \multirow{2}{*}{\multicolumn{2}{|c|}{$\begin{array}{l}\text { Research } \\
\text { variables }\end{array}$}} & \multirow{2}{*}{$\begin{array}{l}\text { Measurement } \\
\text { unit }\end{array}$} & \multirow{2}{*}{$\begin{array}{l}\text { Variance } \\
\text { source }\end{array}$} & \multirow{2}{*}{ Mean } & \multirow{2}{*}{ SD } & \multicolumn{3}{|c|}{$\begin{array}{c}\text { Significance of means' } \\
\text { differences }\end{array}$} & \multirow{2}{*}{$\begin{array}{l}\text { L.S.D } \\
\text { VALUE }\end{array}$} \\
\hline & & & & & & Pre & $\begin{array}{c}\text { In- } \\
\text { Between }\end{array}$ & Post & \\
\hline \multirow{24}{*}{$\underbrace{\grave{D}}_{0}$} & \multirow{3}{*}{$\begin{array}{l}\text { Number of raising trunk upwards } \\
\text { from inverted hang on vaulting in } \\
15 \text { second }\end{array}$} & \multirow{3}{*}{ Repetition } & Pre & 8.333 & 0.516 & & 1.5 & 2.5 & \multirow[t]{3}{*}{0.632} \\
\hline & & & In-between & 9.832 & 0.408 & & & 1 & \\
\hline & & & Post & 10.833 & 0.408 & & & & \\
\hline & \multirow{3}{*}{$\begin{array}{l}\text { No of raising legs forward upward } \\
\text { to touch wall high bar by feet } \\
\text { insteps in } 15 \text { second }\end{array}$} & \multirow{3}{*}{ Repetition } & Pre & 8 & 0.894 & & 1.833 & 2.833 & \multirow[t]{3}{*}{0.869} \\
\hline & & & In-between & 9.833 & 0.408 & & & 1 & \\
\hline & & & Post & 10.833 & 0.408 & & & & \\
\hline & \multirow{3}{*}{$\begin{array}{l}\text { No of raising legs backward } \\
\text { upward from laying on horse in } \\
15 \text { seconds }\end{array}$} & \multirow{3}{*}{ Repetition } & Pre & 15.833 & 0.408 & & 1.333 & 2.333 & \multirow[t]{3}{*}{0.578} \\
\hline & & & In-between & 17.1666 & 0.408 & & & 1 & \\
\hline & & & Post & 18.166 & 0.408 & & & & \\
\hline & \multirow{3}{*}{$\begin{array}{l}\text { No of raising legs backward } \\
\text { upward to touch hands in } 15 \text { th }\end{array}$} & & Pre & 12.166 & 0.752 & & 1.833 & 2.833 & 1.201 \\
\hline & & Repetition & In-between & 14 & 0.894 & & & 1 & \\
\hline & & & Post & 15 & 0.894 & & & & \\
\hline & Number of twisting body from & & Pre & 7.666 & 0.516 & & 4 & 6.167 & 0.682 \\
\hline & stand on hand within two circles & Repetition & In-between & 11.666 & 0.516 & & & 2.167 & \\
\hline & in 15 seconds & & Post & 13.833 & 0.408 & & & & \\
\hline & & & Pre & 9.5 & 0.547 & & 1.667 & 2.333 & 0.649 \\
\hline & $\begin{array}{l}\text { Number or pulling with hands } \\
\text { from hanoing in } 15 \text { second }\end{array}$ & Repetition & In-between & 11.166 & 0.408 & & & 0.667 & \\
\hline & & & Post & 11.833 & 0.408 & & & & \\
\hline & & & Pre & 17.833 & 0.752 & & 2.667 & 3.667 & 1.145 \\
\hline & $\begin{array}{l}\text { Number of arms bending from } \\
\text { horizontal lying in } 15 \text { seconds }\end{array}$ & Repetition & In-between & 20.5 & 0.836 & & & 1 & \\
\hline & & & Post & 21.5 & 0.836 & & & & \\
\hline & & & Pre & 13.5 & 0.547 & & 0.833 & 3 & 0.76 \\
\hline & Time of climbing 5 meters rope & Second & In-between & 12.666 & 0.516 & & & 2.167 & \\
\hline & & & Post & 10.5 & 0.547 & & & & \\
\hline & No of lifting with strength to & & Pre & 3 & 0.894 & & 4.667 & 6.333 & 1.299 \\
\hline & stand on hands from angle pivot & Repetition & In-between & 7.666 & 0.816 & & & 1.667 & \\
\hline & on parallel bars & & Post & 9.333 & 1.032 & & & & \\
\hline & & & Pre & 52.5 & 1.87 & & 9.667 & 12 & 2.472 \\
\hline & Time of Standing on hands & Second & In-between & 62.166 & 1.416 & & & 2.333 & \\
\hline & & & Post & 64.5 & 1.87 & & & & \\
\hline$\underset{\circlearrowright}{\Xi}$ & & & Pre & 9 & 0.894 & & 8.5 & 13.5 & 2.658 \\
\hline 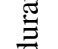 & stability time in $\mathrm{V}$ angle & Second & In-between & 17.5 & 2.949 & & & 5 & \\
\hline 产 & & & Post & 22.5 & 1.048 & & & & \\
\hline 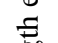 & Number of double leg circles & & Pre & 13.333 & 0.516 & & 12.5 & 19 & 1.437 \\
\hline$\stackrel{50}{0}$ & from parallel support. & Repetition & In-between & 25.832 & 1.471 & & & 6.5 & \\
\hline$\stackrel{巳}{\mathscr{\Xi}}$ & & & Post & 32.333 & 0.816 & & & & \\
\hline & & & Pre & 15.333 & 0.516 & & 12.833 & 18 & 1.238 \\
\hline & Number of double leg circles & Repetition & In-between & 28.166 & 1.169 & & & 5.166 & \\
\hline & Irom cross support. & & Post & 33.333 & 0.816 & & & & \\
\hline & & & Pre & 3.833 & 0.752 & & 1.667 & 3.333 & 0.673 \\
\hline & Time of horizontal pivot & Second & In-between & 5.5 & 0.547 & & & 1.666 & \\
\hline & & & Post & 7.166 & 0.752 & & & & \\
\hline & & & Pre & 26.5 & 0.547 & & 1.667 & 7.833 & 1.247 \\
\hline$\stackrel{\mathscr{D}}{=}$ & Shoulders bend's motor range & Mark & In-between & 32.166 & 0.752 & & & & \\
\hline 콘 & & & Post & 34.333 & 1.211 & & & & \\
\hline อ̆ & & & Pre & 82.666 & 0.516 & & 4.5 & 6.333 & 1.273 \\
\hline$\sum^{0}$ & Shoulder extension's motor range & Mark & In-between & 87.166 & 1.169 & & & 1.833 & \\
\hline & & & Post & 89 & 0.894 & & & & \\
\hline & & & Pre & 4.333 & 0.258 & & 2.25 & 4 & 0.429 \\
\hline & es evaluation for skill performance & Mark & In-between & 6.583 & 0.276 & & & 1.75 & \\
\hline & & & Post & 8.333 & 0.258 & & & & \\
\hline
\end{tabular}


Figure (2)

Statistical significance of basic variables, physical tests and measurements, judges scores for skill performance level of research groups during experiment

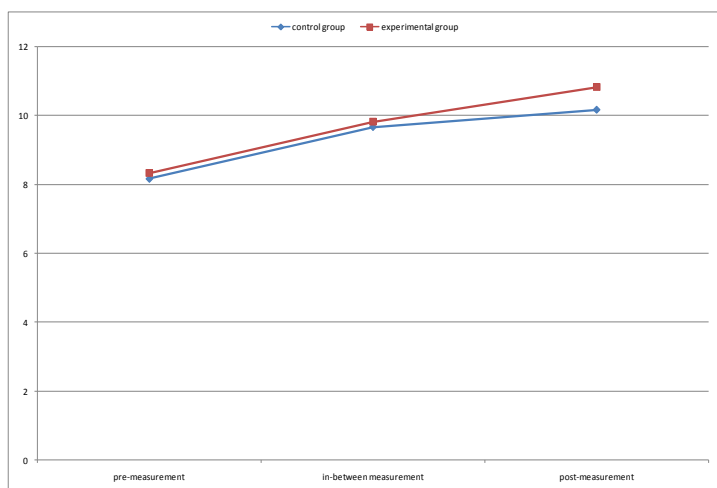

Number of raising trunk upwards from inverted hang on vaulting in 15 second

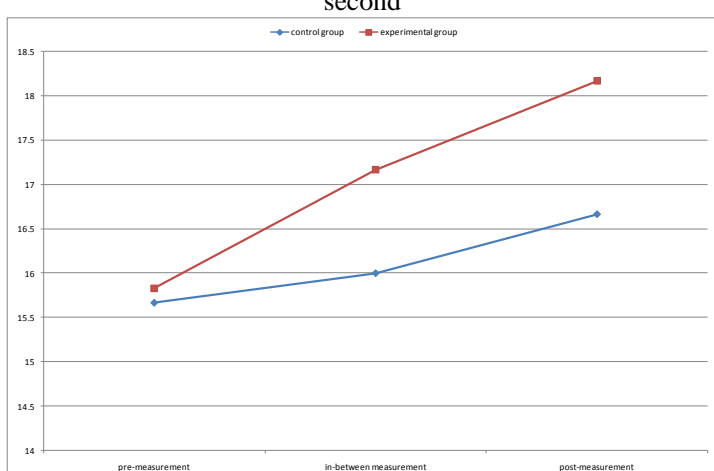

No of raising legs backward upward from laying on horse in 15 seconds

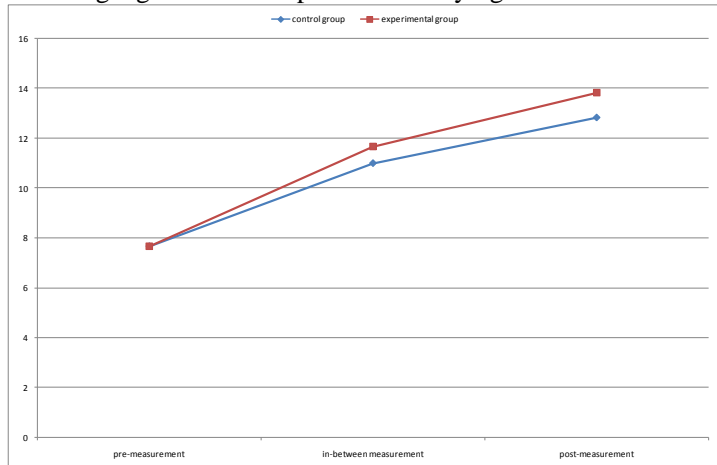

Number of twisting body from stand on hand within two circles in 15 seconds

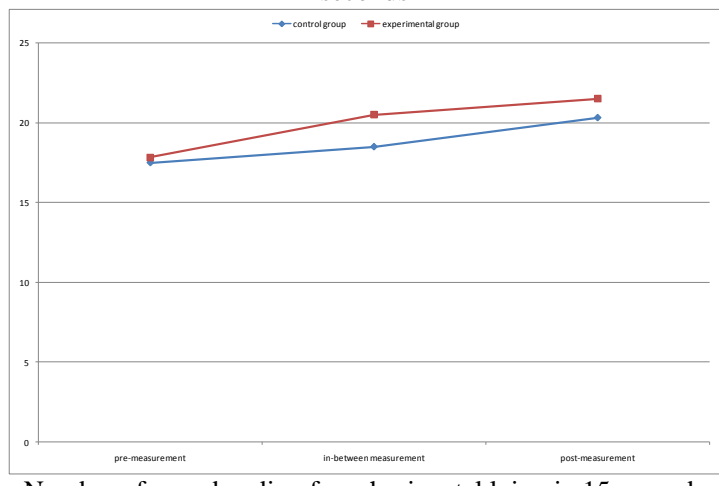

Number of arms bending from horizontal lying in 15 seconds

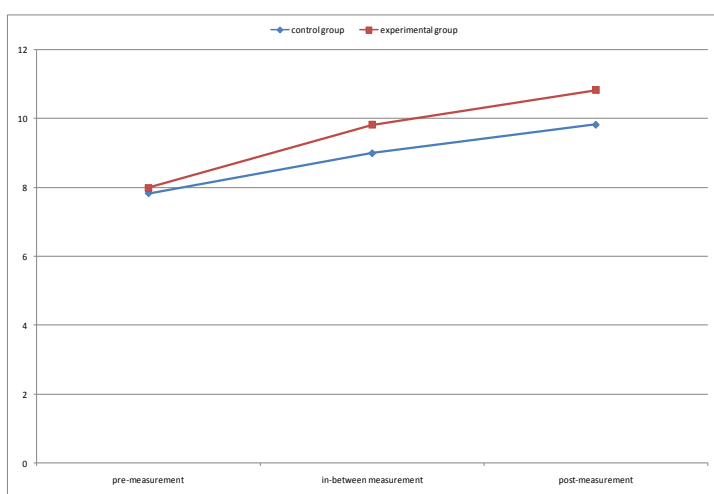

No of raising legs forward upward to touch wall high bar by feet insteps in 15 second

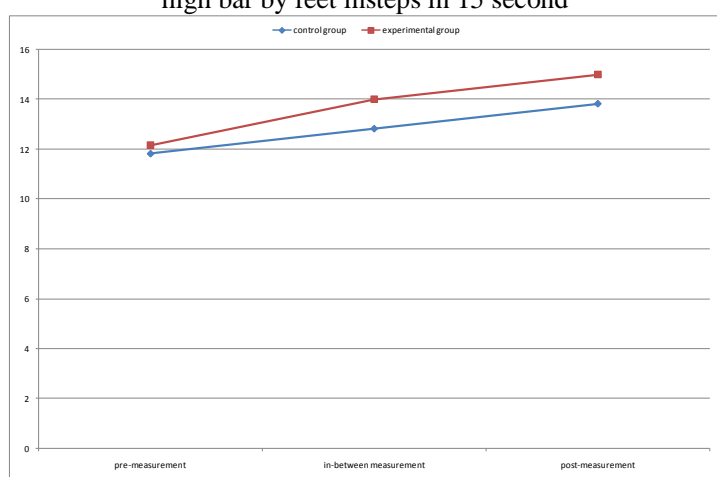

No of raising legs backward upward to touch hands in 15 th

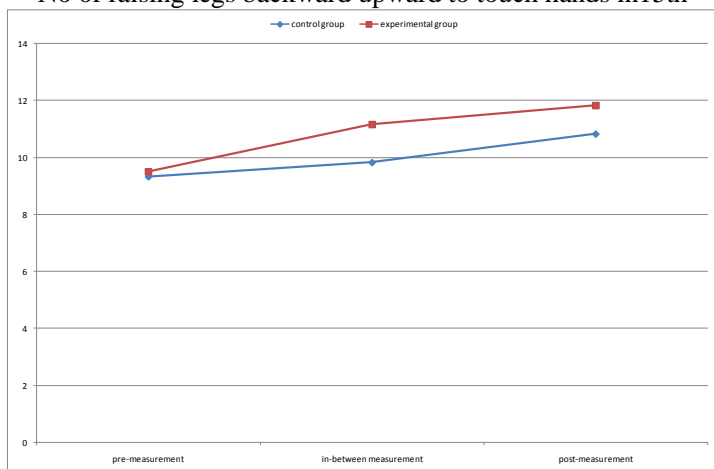

Number of pulling with hands from hanging in 15 second

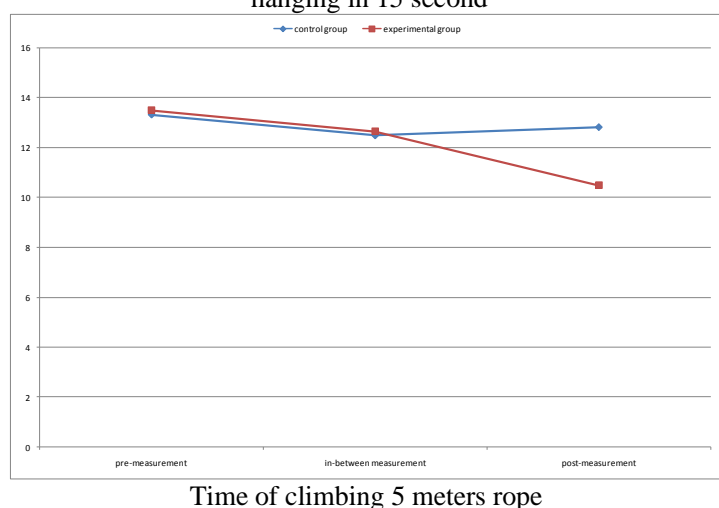

Time of climbing 5 meters rope 
Figure (2) (Continue)

Statistical significance of basic variables, physical tests and measurements, judges scores for skill performance level of research groups during experiment

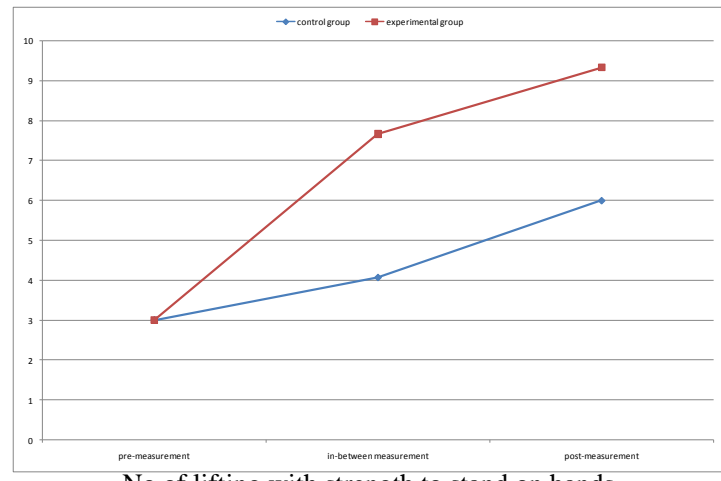

No of lifting with strength to stand on hands from anole nivot on narallel hars (numher)

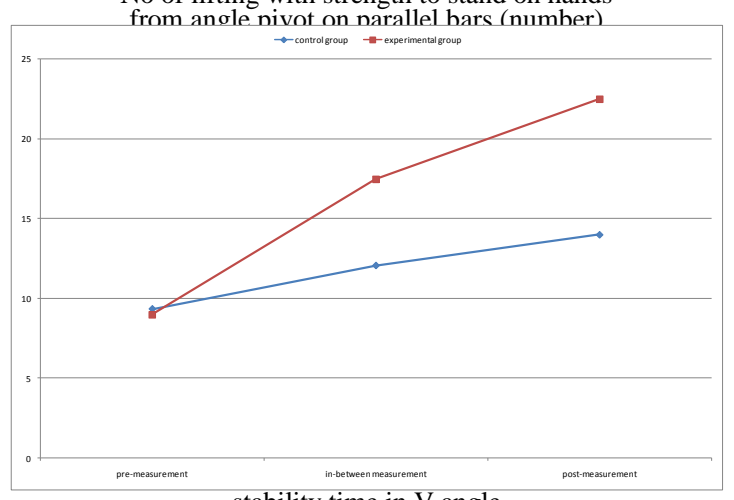

stahilitv time in $\mathrm{V}$ ancle

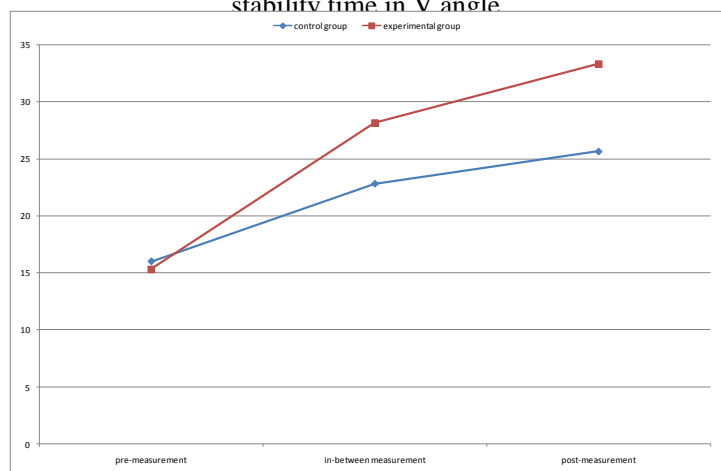

Number of double leo circles from cross sunnort

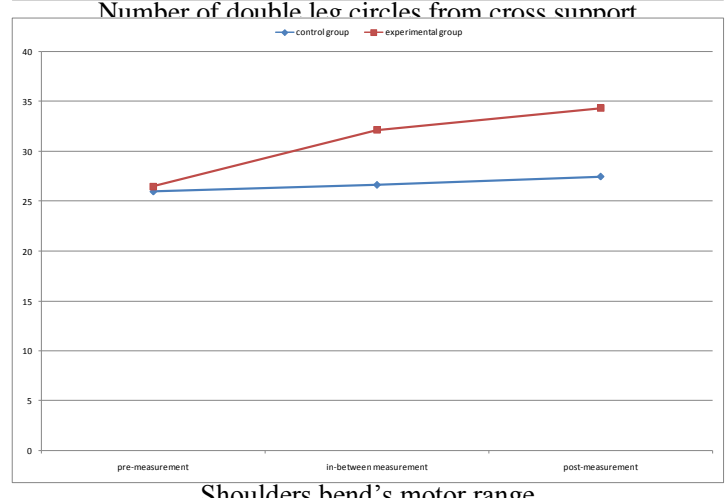

Shoulders bend's motor range

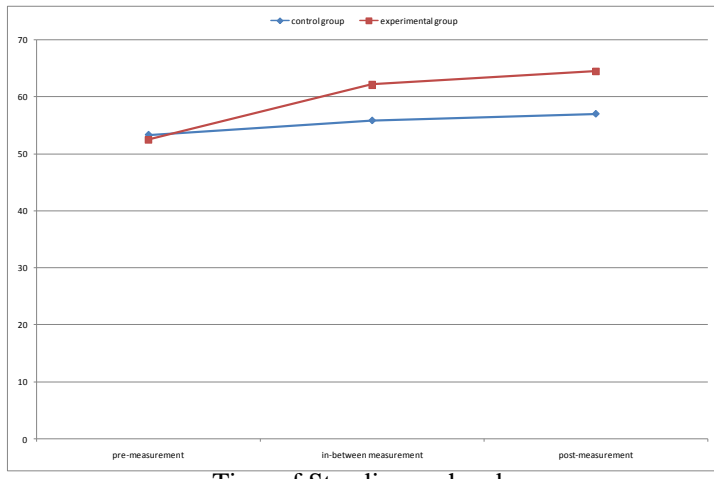

Time of Standing on hands

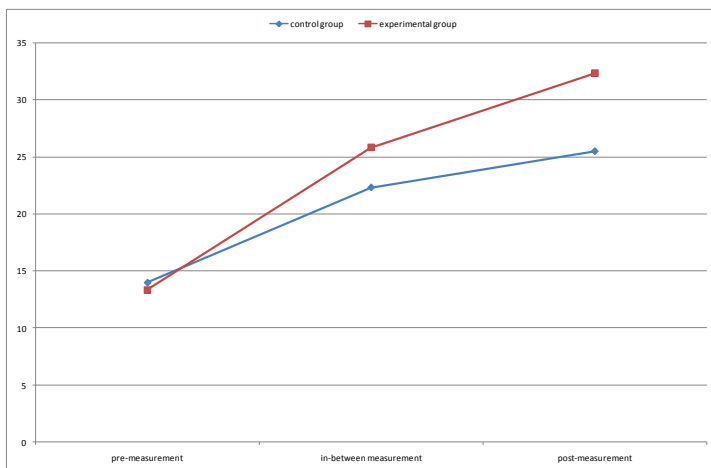

Number of double leg circles from narallel sunnort

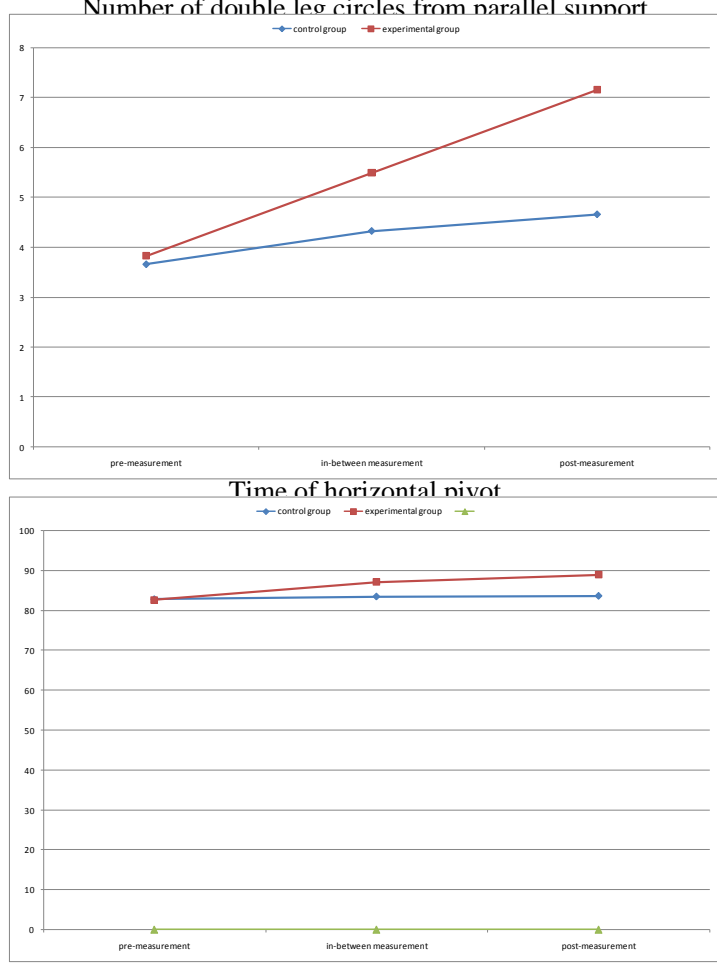

Shoulder extension's motor range 
Figure (2) (Continue)

Statistical significance of basic variables, physical tests and measurements, judges scores for skill performance level of research groups during experiment

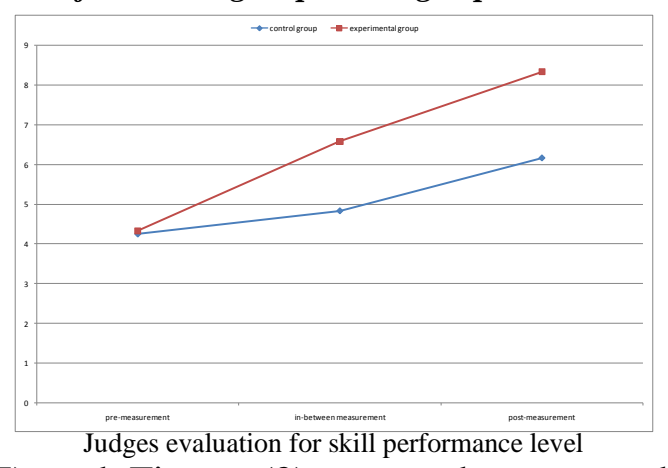

Results of tables No. (6), (7) and Figure (2) which displays Statistical significance of basic variables, physical tests and measurements, judges scores for skill performance level of experimental group before, during and after experiment reveal existence of statistically significant differences at 0.05 level in all power measurements; for example number of body twisting from inverted hang to measure the abdominal muscles power was 8.333 times before experiment and increased to 9.832 times in middle of the experiment, at the end of the experiment it reached 10.833 times and there was statistically significant difference between these values as $F$ value $=47.500$

Same case was repeated for all strength endurance measurements, for example No of lifting with strength to stand on hands from angle pivot on parallel bars for measuring strength endurance for shoulder belt and back muscles was 3 times before experiment increased to 7.666 times in middle of the experiment, at the end of the experiment it reached 9.333 times and there was statistically significant difference between these values as $\mathrm{F}$ value $=76.579$, same was for motor range measurement for shoulder joints bending and extending where $\mathrm{F}$ were 126.214, 78.562 respectively

A well as for judges evaluation for skill performance level for skill under study during the experiment where there were statistically significant differences at 0.05 level where $F$ was $=263.182$, with calculating Lowest significance difference (LSD) for the difference between means that shows significant differences the following were extracted:

- For the differences between physical measurements and tests (power, strength endurance and motor range), as well as judges evaluation for skill performance level before and in middle of experiment, all differences was statistically significant as LSD were 0.632- 0.869- 0.578- 1.201- 0.682$1.145-\quad 0.760-1.299-2.472-\quad 2.658-1.437-$ $1.238-\quad 0.673-1.247-\quad 1.273-0.429$ respectively

- The same for the differences between physical measurements and tests, as well as judges evaluation for skill performance in middle of experiment and after the experiment where most differences $(82.35 \%)$ were statistically significant at 0.05 as LSD were like what mentioned in previous paragraph.

- The same for the differences between physical measurements and tests, as well as judges evaluation for skill performance before and after experiment where all differences were statistically significant at 0.05 as LSD were like what mentioned previously.

From the above mentioned, we can say that experimental group which followed the proposed specific program using special exercises for developing power, strength endurance, flexibility and motor range, in addition to the unified skill program has made remarkable progress significant at 0.05 level whether in physical measurement and tests or judges evaluation for skill performance through research stages either in middle of it or after it comparing with level before experiment.

B. Results and discussion for control group during the experiment 
Table (8)

Statistical significance of basic variables, physical tests and measurements, judges scores for skill performance level of control group during experiment

\begin{tabular}{|c|c|c|c|c|c|c|c|c|c|}
\hline \multirow{2}{*}{\multicolumn{2}{|c|}{$\mathrm{P}_{\text {Research }}^{\begin{array}{c}\text { Statistical } \\
\text { significance }\end{array}}$}} & \multirow{3}{*}{$\begin{array}{c}\text { Measurement } \\
\text { unit }\end{array}$} & \multicolumn{2}{|c|}{$\begin{array}{c}\text { Pre- } \\
\text { measurement }\end{array}$} & \multicolumn{2}{|c|}{$\begin{array}{c}\text { In-between } \\
\text { measurement }\end{array}$} & \multicolumn{2}{|c|}{$\begin{array}{c}\text { Post- } \\
\text { measurement }\end{array}$} & \multirow{2}{*}{$\mathrm{F}$ value } \\
\hline & & & Mean & $\pm \mathrm{SD}$ & Mean & $\pm \mathrm{SD}$ & Mean & $\pm \mathrm{SD}$ & \\
\hline \multirow{8}{*}{ 㐫 } & $\begin{array}{l}\text { Number of raising trunk } \\
\text { upwards from inverted hang } \\
\text { on vaulting in } 15 \text { second }\end{array}$ & & 8.166 & 0.408 & 9.167 & 0.408 & 10.166 & 0.408 & 26.000 \\
\hline & $\begin{array}{l}\text { No of raising legs forward } \\
\text { upward to touch wall high } \\
\text { bar by feet insteps in } 15 \\
\text { second }\end{array}$ & $\begin{array}{l}\text { Repetition } \\
\quad / \text { sec }\end{array}$ & 7.833 & 0.752 & 9.000 & 0.894 & 9.833 & 0.752 & 9.397 \\
\hline & $\begin{array}{l}\text { No of raising legs backward } \\
\text { upward from laying on horse } \\
\text { in } 15 \text { seconds }\end{array}$ & $\begin{array}{l}\text { Repetition } \\
\quad / \mathrm{sec}\end{array}$ & 15.666 & 0.516 & 16.000 & 0.632 & 16.666 & 0.516 & 5.000 \\
\hline & $\begin{array}{l}\text { No of raising legs backward } \\
\text { upward to touch hands in } 15 \text { th }\end{array}$ & $\begin{array}{l}\text { Repetition } \\
\text { /sec }\end{array}$ & 11.833 & 0.752 & 12.833 & 0.753 & 13.833 & 0.752 & 10.588 \\
\hline & $\begin{array}{l}\text { Number of twisting body } \\
\text { from stand on hand within } \\
\text { two circles in } 15 \text { seconds }\end{array}$ & $\begin{array}{l}\text { Repetition } \\
\quad / \mathrm{sec}\end{array}$ & 7.666 & 0.516 & 11.000 & 0.632 & 12.833 & 0.752 & 100.135 \\
\hline & $\begin{array}{l}\text { Number of pulling with } \\
\text { hands from hanging in } 15 \\
\text { second }\end{array}$ & $\begin{array}{l}\text { Repetition } \\
\quad / \mathrm{sec}\end{array}$ & 9.333 & 0.516 & 9.833 & 0.752 & 10.833 & 0.752 & 7.500 \\
\hline & $\begin{array}{l}\text { Number of arms bending } \\
\text { from horizontal lying in } 15 \\
\text { seconds }\end{array}$ & $\begin{array}{l}\text { Repetition } \\
\quad / \mathrm{sec}\end{array}$ & 17.500 & 0.547 & 18.500 & 0.547 & 20.333 & 0.516 & 20.000 \\
\hline & Time of climbing 5 meters rope & second & 13.333 & 0.516 & 12.500 & 2.345 & 12.833 & 2.639 & 0.510 \\
\hline \multirow{6}{*}{ 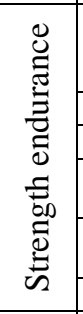 } & $\begin{array}{l}\text { No of lifting with strength to stand } \\
\text { on hands from angle pivot on } \\
\text { parallel bars (number) }\end{array}$ & Repetition & 3.000 & 0.632 & 4.066 & 0.516 & 6.000 & 0.894 & 27.727 \\
\hline & Time of Standing on hands & second & 53.333 & 1.751 & 55.833 & 0.752 & 57.000 & 0.894 & 14.348 \\
\hline & stability time in $\mathrm{V}$ angle & Second & 9.333 & 0.516 & 12.666 & 0.516 & 14.000 & 0.532 & 111.429 \\
\hline & $\begin{array}{c}\text { Number of double leg circles from } \\
\text { parallel support }\end{array}$ & Count & 14.000 & 0.632 & 22.333 & 1.632 & 25.500 & 1.048 & 152.440 \\
\hline & $\begin{array}{c}\text { Number of double leg circles from } \\
\text { cross support }\end{array}$ & Count & 16.000 & 0.984 & 22.833 & 1.722 & 25.666 & 1.032 & 91.966 \\
\hline & Time of horizontal pivot & Second & 3.667 & 0.516 & 4.333 & 0.516 & 4.666 & 0.516 & 5.833 \\
\hline \multirow{3}{*}{ 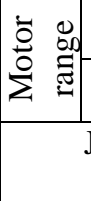 } & Shoulders bend's motor range & Mark & 26.000 & 0.632 & 26.666 & 0.516 & 27.500 & 0.547 & 10.516 \\
\hline & Shoulder extension's motor range & Mark & 82.833 & 0.752 & 83.500 & 0.547 & 83.666 & 0.816 & 2.283 \\
\hline & $\begin{array}{l}\text { Judges evaluation for skill } \\
\text { performance level }\end{array}$ & Mark & 4.250 & 0.273 & 4.833 & 0.752 & 6.161 & 0.316 & 33.090 \\
\hline
\end{tabular}

F significant $\quad($ at 0.01 level $)=3.68$

$($ at 0.01 level $)=6.26$ 
Table (9)

Significance of difference between the three measurements (pre, in-between and post) for basic variables, physical tests and measurements, judges scores for skill performance level of experimental group using LSD test

\begin{tabular}{|c|c|c|c|c|c|c|c|c|c|}
\hline \multirow{2}{*}{\multicolumn{2}{|c|}{$\begin{array}{l}\text { Research } \\
\text { variables }\end{array} \quad \begin{array}{c}\text { Statistical } \\
\text { significance }\end{array}$}} & \multirow{2}{*}{$\begin{array}{l}\text { Measurement } \\
\text { unit }\end{array}$} & \multirow{2}{*}{$\begin{array}{l}\text { Variance } \\
\text { source }\end{array}$} & \multirow{2}{*}{ Mean } & \multirow{2}{*}{ SD } & \multicolumn{3}{|c|}{$\begin{array}{c}\text { Significance of means' } \\
\text { differences }\end{array}$} & \multirow{2}{*}{$\begin{array}{l}\text { L.S.D } \\
\text { VALUE }\end{array}$} \\
\hline & & & & & & Pre & In-Between & Post & \\
\hline \multirow{24}{*}{ 㐫 } & \multirow{3}{*}{$\begin{array}{l}\text { Number of raising trunk upwards } \\
\text { from inverted hang on vaulting in } \\
15 \text { second }\end{array}$} & \multirow{3}{*}{ Repetition } & Pre & 8.166 & 0.408 & & 1.000 & 2.000 & \multirow{3}{*}{0.578} \\
\hline & & & In-between & 9.167 & 0.408 & & & 1.000 & \\
\hline & & & Post & 10.166 & 0.408 & & & & \\
\hline & \multirow{3}{*}{$\begin{array}{l}\text { No of raising legs forward upward } \\
\text { to touch wall high bar by feet } \\
\text { insteps in } 15 \text { second }\end{array}$} & \multirow{3}{*}{ Repetition } & Pre & 7.833 & 0.752 & & 1.167 & 2.000 & \multirow{3}{*}{1.135} \\
\hline & & & In-between & 9.000 & 0.894 & & & 0.833 & \\
\hline & & & Post & 9.833 & 0.752 & & & & \\
\hline & \multirow{3}{*}{$\begin{array}{l}\text { No of raising legs backward } \\
\text { upward from laying on horse in } 15 \\
\text { seconds }\end{array}$} & \multirow{3}{*}{ Repetition } & Pre & 15.666 & 0.516 & & 0.333 & 1.000 & \multirow{3}{*}{0.788} \\
\hline & & & In-between & 16.000 & 0.632 & & & 0.667 & \\
\hline & & & Post & 16.666 & 0.516 & & & & \\
\hline & \multirow{3}{*}{$\begin{array}{l}\text { No of raising legs backward } \\
\text { upward to touch hands in } 15 \text { th }\end{array}$} & & Pre & 11.833 & 0.752 & & 1.000 & 2.000 & \\
\hline & & Repetition & In-between & 12.833 & 0.753 & & & 1.000 & 1.065 \\
\hline & & & Post & 13.833 & 0.752 & & & & \\
\hline & Number of twisting body from & & Pre & 7.666 & 0.516 & & 3.333 & 5.167 & \\
\hline & stand on hand within two circles in & Repetition & In-between & 11.000 & 0.632 & & & 1.833 & 0.906 \\
\hline & 15 seconds & & Post & 12.832 & 0.752 & & & & \\
\hline & & & Pre & 9.333 & 0.516 & & 0.500 & 1.500 & \\
\hline & Number of pulling with hands & Repetition & In-between & 9.833 & 0.752 & & & 1.000 & 0.966 \\
\hline & & & Post & 10.833 & 0.752 & & & & \\
\hline & & & Pre & 17.500 & 0.546 & & 1.000 & 2.000 & \\
\hline & Number of arms bending from & Repetition & In-between & 18.500 & 0.547 & & & 1.000 & 0.774 \\
\hline & & & Post & 20.333 & 0.516 & & & & \\
\hline & & & Pre & 13.333 & 0.516 & & 1.167 & 0.833 & \\
\hline & Time of climbing 5 meters rope & Second & In-between & 12.500 & 2.345 & & & 0.333 & 2.914 \\
\hline & & & Post & 12.833 & 2.639 & & & & \\
\hline & No of lifting with strength to stand & & Pre & 3.000 & 0.632 & & 1.667 & 3.000 & \\
\hline & on hands from angle pivot on & Repetition & In-between & 4.066 & 0.516 & & & 1.333 & 0.989 \\
\hline & parallel bars & & Post & 6.000 & 0.894 & & & & \\
\hline & & & Pre & 53.332 & 1.751 & & 2.500 & 3.667 & \\
\hline & Time of Standing on hands & Second & In-between & 55.833 & 0.752 & & & 1.167 & 1.719 \\
\hline & & & Post & 57.000 & 0.894 & & & & \\
\hline$\underset{\Xi}{\Xi}$ & & & Pre & 9.333 & 0.516 & & 3.333 & 4.667 & \\
\hline$\stackrel{\pi}{\Xi}$ & stability time in $\mathrm{V}$ angle & Second & In-between & 12.066 & 0.516 & & & 1.333 & 0.788 \\
\hline$\vec{E}$ & & & Post & 14.000 & 0.532 & & & & \\
\hline$\stackrel{0}{=}$ & Number of double leg circles from & & Pre & 14.000 & 0.632 & & 8.333 & 11.500 & \\
\hline $\overrightarrow{50}$ & parallel support & Repetition & In-between & 22.332 & 1.632 & & & 3.167 & 1.667 \\
\hline$\stackrel{D}{\mathscr{D}}$ & & & Post & 25.500 & 1.048 & & & & \\
\hline & & & Pre & 16.000 & 0.894 & & 6.833 & 9.667 & \\
\hline & Number of double leg circles from & Repetition & In-between & 22.833 & 1.722 & & & 2.833 & 1.795 \\
\hline & & & Post & 25.666 & 1.032 & & & & \\
\hline & & & Pre & 3.667 & 0.516 & & 0.666 & 0.999 & \\
\hline & Time of horizontal pivot & Second & In-between & 4.333 & 0.516 & & & 0.333 & 0.321 \\
\hline & & & Post & 4.666 & 0.516 & & & & \\
\hline & & & Pre & 26.000 & 0.632 & & 0.667 & 1.500 & \\
\hline$: 0$ & Shoulders bend's motor range & Mark & In-between & 26.666 & 0.516 & & & 0.833 & 0.802 \\
\hline స్తు & & & Post & 27.500 & 0.547 & & & & \\
\hline$\ddot{0}$ & & & Pre & 82.833 & 0.752 & & 0.667 & 0.833 & \\
\hline$\sum^{0}$ & Shoulder extension's motor range & Mark & In-between & 83.500 & 0.547 & & & 0.166 & 1.011 \\
\hline & & & Post & 83.666 & 0.816 & & & & \\
\hline & & & Pre & 4.250 & 0.273 & & 0.583 & 2.250 & \\
\hline & res evaluation for skill performance & Mark & In-between & 4.833 & 0.752 & & & 1.667 & 0.702 \\
\hline & & & Post & 6.162 & 0.316 & & & & \\
\hline
\end{tabular}

Results of tables No. (8), (9) and Figure (2) significant differences at 0.05 level in all power which displays Statistical significance of basic measurements; except for time of rope (5M) variables, physical tests and measurements, climbing where there was no statistically judges scores for skill performance level of significant differences at 0.05 level, for example control group before, during and after number of raising trunk upwards from inverted experiment reveal existence of statistically hang to measure the abdominal muscles power 
was 8.166 times before experiment and increased to 9.167 times in middle of the experiment, at the end of the experiment it reached 10.833 times and with calculate the significant degree between these measurements reveal existence statistically significant difference as $\mathrm{F}$ value $=36.00$.

Same case was repeated for all strength endurance measurements, for example number of lifting with strength to stand on hands from angle support on parallel bars for measuring strength endurance for shoulder belt and back muscles was 3 times before experiment increased to 4.066 times in middle of the experiment, at the end of the experiment it reached 6.000 times after the experiment and with calculate the significant degree between these measurements reveal existence of statistically significant difference as $\mathrm{F}$ value $=$ 27.727. For motor range measurement for shoulder joints bending reveal there was statistically significant differences at 0.05 level where $\mathrm{F}$ were 10.516. For motor range measurement for shoulder joints extending reveal there was no statistically significant differences at 0.05 level $\mathrm{F}$ was $\quad 2.283$.

There were statistically significance difference at 0.05 level in judges evaluation for skill performance level for skill under study during the experiment where $\mathrm{F}$ was 33.090 , with calculating Lowest significance difference (LSD) for the difference between means that shows significant differences the following were extracted:

- For the differences between physical measurements and tests (power, strength endurance and motor range), as well as judges evaluation for skill performance level for skill under study before and middle of experiment, reveal some differences - which form $58.833 \%$ from total differences) were statistically significant at 0.05 level as LSD were 0.578- 1.135- 0.906- 0.774- 0.989$1.719-0.788-1.667-1.795-0.312$ respectively.
- For differences between physical measurements and tests, as well as judges evaluation for skill performance for skill under study in middle of experiment and after the experiment reveal most differences (which form $64.7065 \%$ from total differences) were statistically significant at 0.05 level as LSD were like what mentioned in previous paragraph.

- Also for differences between physical measurements and tests, as well as judges evaluation for skill performance for skill under study before and after experiment reveal most differences (which form 88.235 from total differences) were statistically significant at 0.05 level as LSD were like what mentioned previously.

With calculating Lowest significance difference (LSD) for the differences between means found remarkable progress for the measurements in middle and after the experiment comparing with level before conducting the experiment and with significant differences at 0.05 level.

From the above mentioned, we can say that control group which followed a program for developing power, strength endurance, flexibility and motor range, in addition to the unified skill program using total method and trial and error for education the skill, has made remarkable progress at 0.05 level whether in physical measurement and tests or in judges evaluation for skill performance for the skill (research subject) through research stages either in middle of it or after it comparing with level before experiment

So it is possible to return progress achieved by each group to the nature of training program it followed, especially if we note that both groups were equivalent before experiment and they face same conditions during experiment except for difference in training nature and program for each of them. 
Table (10)

Improvement percentage or research groups during experiment

\begin{tabular}{|c|c|c|c|c|c|c|c|c|c|c|c|c|c|c|c|c|c|}
\hline \multirow[b]{2}{*}{ 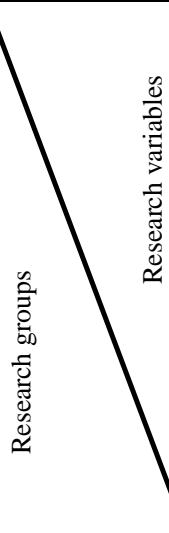 } & \multicolumn{8}{|c|}{ Power } & \multicolumn{6}{|c|}{ Strength endurance } & \multicolumn{2}{|c|}{$\begin{array}{l}\text { Motor } \\
\text { range }\end{array}$} & \multirow[b]{2}{*}{ 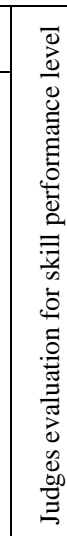 } \\
\hline & 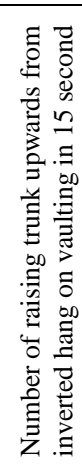 & 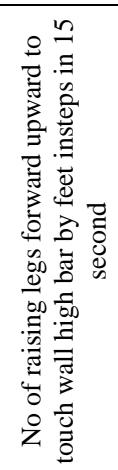 & 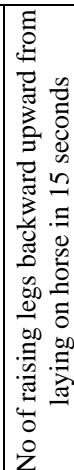 & 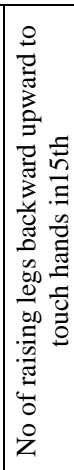 & 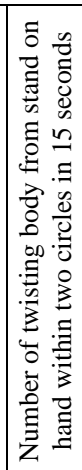 & 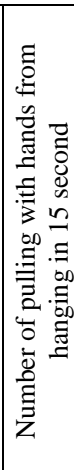 & 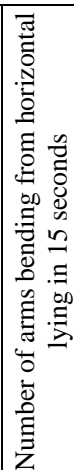 & 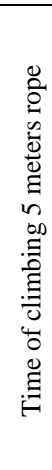 & 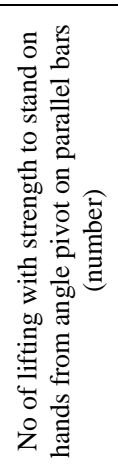 & 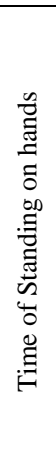 & 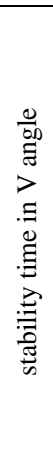 & 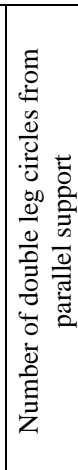 & 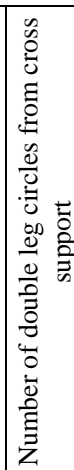 & 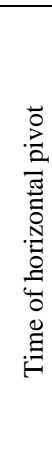 & 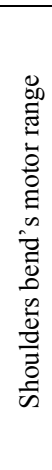 & 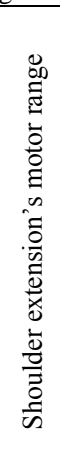 & \\
\hline Experimental & $\begin{array}{l}\frac{\delta}{8} \\
\dot{0} \\
\dot{m}\end{array}$ & 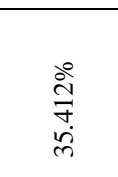 & 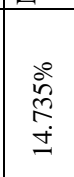 & $\begin{array}{l}\stackrel{0}{0} \\
\infty \\
\ddot{\lambda} \\
\tilde{d}\end{array}$ & 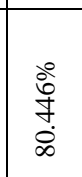 & 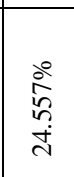 & 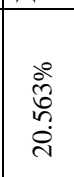 & $\begin{array}{l}\text { 今े } \\
\text { ते } \\
\text { ते }\end{array}$ & $\begin{array}{l}0 \\
\stackrel{0}{\Delta} \\
\dot{\pi}\end{array}$ & $\begin{array}{l}\stackrel{8}{0} \\
0 \\
\infty \\
\text { i }\end{array}$ & 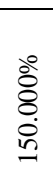 & 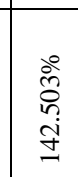 & $\begin{array}{l}\stackrel{D}{2} \\
\stackrel{\rho}{\Xi}\end{array}$ & 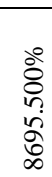 & $\begin{array}{l}\stackrel{0}{2} \\
\text { ñ } \\
\text { ते }\end{array}$ & $\frac{8}{8}$ & $\begin{array}{l}\frac{8}{7} \\
\text { a } \\
\text { in }\end{array}$ \\
\hline Control & $\begin{array}{l}\stackrel{\circ}{\frac{9}{g}} \\
\stackrel{d}{d}\end{array}$ & 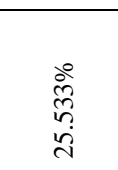 & $\begin{array}{l}\stackrel{0}{0} \\
\infty \\
\overbrace{0}^{\infty}\end{array}$ & $\begin{array}{l}\stackrel{\circ}{\circ} \\
\stackrel{8}{0} \\
\stackrel{0}{0}\end{array}$ & $\frac{\stackrel{\circ}{a}}{\frac{9}{+}}$ & 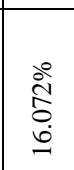 & 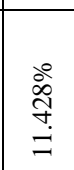 & 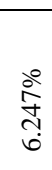 & $\begin{array}{l}8 \\
8 \\
8 \\
8\end{array}$ & $0^{\infty}$ & 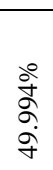 & $\begin{array}{l}\stackrel{\Delta}{N} \\
\underset{\infty}{\Delta} \\
\infty\end{array}$ & $\begin{array}{l}\frac{0}{\infty} \\
\frac{1}{ \pm} \\
8 \\
0\end{array}$ & 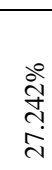 & 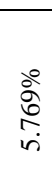 & 客 & 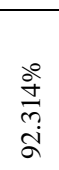 \\
\hline
\end{tabular}

Table 10 which displays improvement percentage of research groups during experiment reveal that experimental group improvement percentage is higher than that or control group in all physical measurements and tests and arbitrators scores for skill performance level for skill under discussion.

This demonstrates that improvement percentage for experimental group that followed the proposes program using specific exercises were higher than that for control group, researcher return this difference in improvement rate is the following reasons:

- Deficiencies in traditional program followed by the control group.

- Proposed specific exercises focused on all forms of strength related to skill performance for skill under study., this confirms the high level of skill performance which demonstrates the positivity of specific exercises for Russian skill on pommel horse.

Through the research findings, it is clear that proposed specific exercises is credited for developing technical aspects and this is due to alerting sensory receptors in muscles and thus develop kinetic sense, and special exercises similarity with technical performance work to make balance between (arousal - stop) processes for nervous activity and this leads to player quickly enter to mastery and fixing stages, this is confirmed by Ahmed El-Hadu (1997,p292), quoting from Heinz that improving and developing performance could be done through development of physical and motor characteristics, which should be available in gymnastics junior, by setting the appropriate means and methods for their development in a scientific way, in addition, to that they save time and effort and contribute to performance level development in good manner.

This also is consistent with what Talha Hussain (1993, p21) and Kristy Browland (1988, p138) mentioned that specific exercises is highest specialization degree in skill performance development of performance as for quantity, quality and timing according to the instantaneous uses of muscles or muscle groups within the skill performance.

It can be seen that specific exercises led to development of physical fitness elements, especially muscular strength, which led to raise efficiency of muscle groups working on the joints for Russian skill, which in turn increased ability to control body parts and saving effort with a consistency between body movements, which led to develop motor paths, reduce education time in order to reach good performance level in the shortest possible time, it is also evidenced that coach full 
understanding of muscular work during skill performance and then set proposed skill and physical exercises similar to skill performance with diversity muscle using methods led to positive results, both in physical fitness elements level and skill performance level, and it is also clear that strength training is an essential basis for raising achievement because it improves neuromuscular functions increasing its ability to transform energy and deepen settings and control paths giving more effective muscle to, Through this player can distribute strength in better way, and most important training methods are which its partial structure match power and time path of competition exercises and also linked to develop special physical quality abilities relate to performance type from one side, and from the other side characterized with the ability to provide training on the skill itself (Gensen , C.R. Nad Hirts, C.C, 1680:pp 134-135) (Mohammed Shehata, 1992 :p172)

From the above progress in skill performance level and physical abilities could be attributed to specific exercises which were progressive in difficulty levels, which led to the improvement of some port movements among it (rhythmic) related to harmony in moving hands and body waiving keeping maintaining body canter of gravity without falling down. Player mastering circle waiving on mushroom apparatus is the basis of Russian skill, also transition of training effect to the skill contributed to research sample mastery of the skill.

\section{Conclusions}

In light of research results it was possible to conclude the following:

- Specific exercise program contributes to improve some physical abilities for Russian skill on a pommel horse for players under 13 years old.

- Specific exercise program lead to increase performance level for the skill under study on pommel horse for players under 13 years old.

- There are differences in players progress level which is due to individual differences represented in the following:
- Differences in physical characteristics levels between players.

- Differences in physical characteristics acquiring level between players

- Differences in skill performance acquiring level between players

- Research sample achieved skill performance in Russian skill arrived to 8.333 marks.

\section{Recommendations}

In light of thesis results, researcher recommends the following:

1. Using proposed training program in this research when teaching Russian skill.

2. More concern to be given to fixed strength endurance especially for shoulders and trunk due to its effect on Russian skill performance on pommel horse and floor apparatus.

3. More concern to be given to develop performance endurance through performance of Russian skill in all its forms on different parts of pommel horse and floor apparatus.

4. conducting similar studies in the skills which coaches find difficulty in teaching or developing.

5. Researcher recommends that Egyptian Federation of Gymnastics in conjunction with faculties of physical education organize courses for gymnastic coaches about basis and rules for setting specific exercises

\section{References}

1. Ahmed El-Hadi Yousuf (1997): systematic methods in gymnastics education and training, Dar El Maaref, Alexandria. (in Arabic language)

2. Ashraf Abdel Aal and Haitham Abdel Alrazeq (2008): Impact of learning technology on acquisition and mastering speed of stocky skill (B) on pommel horse under 12 years old; Fourth Regional Conference of International Council for Health, Physical Education, Recreation, sports and motor expression for the Middle East. Vol. 3, faculty of Physical Education for Men, Alexandria University. (in Arabic language) 
3. Clarke H.H. (1976) : Application of Measurement to Health and Physical Education, 5th education, Publisher: prentice hall, Englewood Cliffs, . New Jersey.

4. Don Tonry (1997): Acquirement routine through Gymnastic apparatus, studies international Canada.

5. ElSayed Mr. Abdel Maksou (1994): sports training theories - guide and amend achievement level track, Hasnaa office, Cairo, (in Arabic language)

6. Fawzi Yakoob, Adel Abdul Basir (1994): Theories and scientific basis in gymnastics training, Dar ELFekr ELaraby, Cairo.: (in Arabic language)

7. Gensen, CR and Hirst, C.C.(1980): Measurement in Physical Education and Athletics', Macmillan Publishing Co., Inc. New York,

8. Hanafi Mahmoud Mukhtar (1988): Foundations of Planning sport training programs, Dar Zahran, Cairo. (in Arabic language)

9. Hosni Sayed Ahmad Hussein(2004): Program using learning technology learning and its impact on development of some physical abilities and learning speed related to American scissor skill (Thomas) on pommel horse, published thesis, Journal of theories and applications, Issue 51, Faculty of Physical Education for men, Alexandria University. (in Arabic language)

10. International Gymnastic Federation (2001): Men's Artistic Gymnastic, code of Points Switzerland, New Version.

11. Kattegat Mohamed Khattab(1987): Exercises for girls, , 4th ed., Dar ELMaaref, Alexandria (in Arabic language)

12. Kristy Browland (1988): Boys Gymnastics rules Brice darbinbulsher ronssas Missouri, U.S.A.

13. Leila Zahran (1982): scientific and practical basis for exercises and technical exercises, Dar Elfekr ElArbi, Cairo. (in Arabic language)

14. Mohab Abdul Razzaq, Mahmoud Mohamed Mohamed Hassan, Mohamed Abdel Aziz(2004): Setting standardized scores for some physical abilities tests of artistic gymnastics juniors under 8-10 years in Egypt, Eighth International Scientific Conference for Physical Education and Sport sciences (5-7th October) vol. 2, Alexandria University. (in Arabic language)

15. Mohamed Ibrahim Shehata (1992: Modern gymnastics guide, 2nd ed., Dar ELMaaref, Alexandria. (in Arabic language)

16. Mohamed Sobhi Hassanein (1995): Measurement and Evaluation in Physical Education, 3rd ed., vol 1, Dar ELfekr El Arabi, Cairo. (in Arabic language)

17. Mohammad Hassan Allawi, Mohamed Nasr El-Din Radwan (1982): Motor performance tests, 1st ed., Dar ELfekr El Arabi, Cairo. (in Arabic language)

18. Mohammad Hassan Allawi, Nasr El-Din Radwan(1979): Measurement in physical Education, Sports, Dar ELfekr El Arabi, Cairo. (in Arabic language)

19. Talha Hussein Husam El-Din (1993): motor and functional basis for sports training, Dar ELfekr ElAarabi, Cairo (in Arabic language)

20. Talha Hussein Husam El-Din, Mustafa Mohamed, Hassan Ali Anis, Ismail Abu Zaid(1993): Specific exercises and its relationship to motor achievement level in gymnastics, Future vision of physical education in Arab World conference, Faculty of Physical Education for Men, Helwan University. (in Arabic language).

21. Tudor o. Bompa (1999): Periodization training for sport, programs for peak strength in 35 sports, human kinetics.

22. Watanbe, M., (1998): Floor Exercise Routine - New concept international Gymnastic,

23. Wesam Shawki Zaki(1996): Impact of proposed training program to develop muscle strength on developing performance level of some skills on pommel horse, Master Thesis, Faculty of Physical Education for Men., Helwan University. (in Arabic language)

24. Yehya Mohammed Saleh (1983): Effect of specific exercise on performance level in gymnastics, published research, Helwan magazine, Vol. 6, Issue 2, Helwan University. (in Arabic language) 
